\title{
STUDIES IN BACCHARIDINAE (ASTERACEAE: ASTEREAE). I: LANUGOTHAMNUS A NEW GENUS FROM SOUTH AMERICA ${ }^{1}$
}

\author{
LEONARDO PAZ DEBLE ${ }^{2}$
}

\begin{abstract}
It is described a new genus of Asteraceae, named Lanugothamnus, to include eighteen species and one subespecies of Baccharis before placed in the subgenus Tarchonanthoides. The genus Lanugothamnus has discussed its infragenerical treatment, being segregated in four subgenera: Lanugothamnus, Toxicothamnus, Curitybenses, and Tarchonanthoides. The subgenus Toxicothamnus is a taxonomic novelty, while the subgenera Curitybenses and Tarchonanthoides are based in Baccharis sect. Curitybenses, and Baccharis subg. Tarchonanthoides, respectively. Two new sections are described: Sericicarpa and Pluricephala. The former belongs to subgenus Lanugothamnus, while the later belongs to subgenus Toxicothamnus. Furthermore, two new species, named Lanugothamnus Anabelae and L. pluricapitulatus are described, illustrated and have their taxonomic affinities discussed. Lectotypes are proposed to names Baccharis artemisioides, B. patens, and B. squarrosa. Baccharis multipaniculata is placed in synonymy with Lanugothamnus scabrifolius. A key to segregate the subgenera and species of Lanugothamnus is given, and the appropriate new combinations are made.
\end{abstract}

Key words: Asteraceae, Baccharis, Compositae, subgenus Tarchonanthoides, nomenclature.

\section{RESUMO}

[Estudos em Baccharidinae (Asteraceae: Astereae). I: Lanugothamnus um novo gênero para a América do Sul].

É descrito um novo gênero de Asteraceae, denominado Lanugothamnus, para incluir dezoito espécies e uma subespécie de Baccharis antes pertencentes ao subgênero Tarchonanthoides. O gênero Lanugothamnus tem seu tratamento infragenérico discutido, sendo segregado em quatro subgêneros: Lanugothamnus, Toxicothamnus, Curitybenses, e Tarchonanthoides. O subgênero Toxicothamnus é uma novidade taxonômica, enquanto os subgêneros Curitybenses e Tarchonanthoides são baseados, respectivamente, em Baccharis sect. Curitybenses, e Baccharis subg. Tarchonanthoides. Duas novas seções são descritas: Sericicarpa e Pluricephala. A primeira pertence ao subgênero Lanugothamnus, enquanto a outra ao subgênero Toxicothamnus. Duas novas espécies, nomeadas Lanugothamnus Anabelae e L. pluricapitulatus são descritas, ilustradas e têm suas afinidades taxonômicas comentadas. Lectótipos são propostos para os nomes Baccharis artemisioides, B. patens e B. squarrosa. Baccharis multipaniculata é colocado na sinonimia de Lanugothamnus scabrifolius. É fornecida uma chave para subgêneros e espécies de Lanugothamnus, e as novas combinações necessárias são feitas.

Palavras-chave: Asteraceae, Baccharis, Compositae, subgênero Tarchonanthoides, nomenclatura.

\section{INTRODUCTION}

Baccharidineae is a New World subtribe of the tribe Astereae including only two genera (Müller 2006) or more than nine genera (Hellwig 1996), and 450-500 species, mainly

1 Recebido em 14-08-2012 e aceito para publicação em 10-09-2012.

2 Curso de Ciências da Natureza, Universidade Federal do Pampa, Rua 21 de Abril 80, Dom Pedrito, Rio Grande do Sul, 96450-000, Brazil.

Email: deble.biol@gmail.com of them consist of shrubby growing principally in South America. In certain areas some species can form dense stands constituting the dominant shrub, e.g., the romerillal in central areas of Argentina, composed principally by $\mathrm{He}$ terothalamus alienus and Pingraea articulata. Similar physiognomy found in southern Brazil is known as vassoural and comprises a number of species of Baccharis, e.g., B. dracunculifolia, $B$. selloi, B. tridentata, B. uncinella, $B$. erioclada, Heterothalamus alienus, and $H$. psiadioides. 
In grasslands many subshrubs and shrubs associated with Poaceae species belong to Baccharidinae, e.g., romerillo-blanco (Baccharis artemisiodes), mio-mio (Baccharis coridifolia), and carqueja (Pingraea crispa). In the high altitude places of Southern Brazil and Central Brazil the "matinha nebular" is composed by several species of Baccharidinae, e.g., Baccharis lateralis, B. lymanii, Pingraea spp., associated with species of Melastomataceae, Fabaceae, Ericaceae, Myrtaceae, Proteaceae, and other Asteraceae. Several species in savannas of South America are adapted to fire, and some species, e.g., Baccharis humilis, Baccharidiopsis pohlii, often bloom after fires. The Puna region in Northwest Argentina and Bolivia is composed by bushes of lejia (Baccharis incarum) and chijua (Baccharis boliviensis), and in the same region, near to rivers and saline places at 3,200-4,600 $\mathrm{m}$ altitude grow the very small and singular $P$ sila caespitosa Phil.

Taxonomic treatment of the subtribe Baccharidinae are available for species of a number of regions, e.g., Argentina (Cabrera 1963, Cabrera 1971, Espinar 1973, Cabrera 1974, Cabrera 1978, Giuliano 2000, Giuliano 2001), Bolivia (Müller 2006), Brazil (Barroso 1976, Oliveira \& Marchiori 2006a, Oliveira \& Marchiori 2006b, Oliveira-Deble 2008, Schneider 2009), Chile (Hellwig 1990), Colombia (Cuatrecasas 1967, 1969), Uruguay (Arechavaleta 1908), Venezuela (Aristiguieta 1964), Central and North America (Nesom 1990a, 1990b, 1998). On the other hand, complete revision of the genera are reduced to few taxa, e.g., Baccharidastrum (Cabrera 1937), Pseudobaccharis (Cabrera 1944), Archibaccharis (Jackson 1975), Baccharidiopsis (Barroso 1975, Barroso 1976), Heterothalamus (Deble et al. 2005), and Heterothalamulopsis (Deble et al. 2005).

Hellwig $(1992,1993)$ has begun to lay an overview of the subtribe Baccharidinae segregating two genera (Pingraea Cass. emend. F. H. Hellw. and Neomolina F. H. Hellw.). In another contribution, he also recognized the genera Baccharidiopsis G. M. Barroso, Pseudobaccharis Cabrera, Stephananthus Lehm., and the informal groups "Lanugobaccharis" and "Baccharis boliviensis" encompassing nine genera in Baccharidinae (Hellwig, 1996).

Nesom (1994) included Pingraea and Neomolina in Baccharis, and more recently the author recognized the fragility of the Hellwig's segregation by reduced number of species investigated and also because Hellwig has not provided a complete review of the groups and species, furthermore according with the Zanowiak's cpDNA study evidenced a broadly defined and largely undivided Baccharis (Nesom 2000).

Deble et al. (2004) described the new genus Heterothalamulopsis from Brazil to place Heterothalamus Wagenitzii. Müller (2006) recognized only the genus Baccharis for South America. Baccharis sensu lato according to Müller (2006) comprises four subgenera, and three groups not attributed to a subgenus. The traditional segregated genus Heterothalamus, and also the probably related Heterothalamulopsis were included without an obvious reason under the subgenus Molina (Müller, 2006: 217-218). Recently, Giuliano \& Freire (2011) have accepted the criteria of Müller and proposed several new sections and new status under Baccharis, mainly of them to include Müller's informal groups.

Until this moment the Baccharidinae are not completely revised and the classical works of Heering (1915) and Malagarriga (1977) comprehend the most important references to knowledge of species of Baccharidinae. Baccharis Linnaeus (1763: 860) is taxonomically poor defined, and until recently the dioecy was considered crucial to distinguish Baccharis from the other genera of the subtribe Baccharidinae. Baccharis in its narrow sense includes only 120 species (Müller, 2006) or more than 200 species (Hellwig, 1996) and can be characterized by tufted indumentum, 
staminate flowers with style nearly capitate, composed by distinct longer median sweeping trichomes, pistillate flowers at the apex 5dentate, pistillate flowers with deciduous pappus, and terete, glabrous, 8-20 ribbed cypselae.

The species here treated are currently recognized into Baccharis subg. Tarchonanthoides, but this group of species has the following crucial attributes: absence of tufted indumentum, pistillate and staminate corolla at the apex papillose lobes, pubescent cypsela and style of staminate flowers with branches covered by abundant sweeping trichomes of equal length.

\section{RESULTS AND DISCUSSIONS}

The most important morphologic features of Baccharidinae are commented, and subsequently a new genus, named Lanugothamnus is described, illustrated and also have its infragenerical treatment discussed. For the comments of the genera was adopted the generical treatment of Hellwig (1996), except by Psila that is treated as segregated of Stephananthus, and Neomolina that is recognized under Baccharidiopsis. The species of Baccharis that will be transferred for Lanugothamnus are treated under Lanugothamnus.

\section{MORPHOLOGY IN BACCHARIDINEAE Growth habit}

Species of Baccharis are frequently subshrubs or shrubs, sometimes with xylopodium. Archibaccharis and Pingraea include many species of woody vines. In Baccharidiopsis some species are weakly woody. Lanugothamnus lychnophorus is a small tree with up to $6 \mathrm{~m}$ high, and $B$. longiattenuata is a tree with up to $15 \mathrm{~m}$ high. On the other hand, Stephananthus junceus has herbaceous habit and flexible stems, and Psila caespitosa is a rhizomatous herb, with less than $3 \mathrm{~cm}$ high.

\section{Foliage}

Leave size and shape show great variability in Baccharidinae. The majority of species of Baccharis have medium-sized leaves with chartaceous, pinnately veined or 3-veined blades. Baccharis notosergila displays linear and deciduous leaves and Baccharis multifolia has very small, and oblong linear leaves, while B. polyphylla has sulcate leaves. Species of Pingraea show large and dentate or serrate leaves; on the other hand some species of Pingraea have winged stems and leaves reduced to small triangular scales. Archibaccharis frequently displays medium-sized leaves, with thin pinnately veined blades. In Heterothalamus the leaves are glutinous and often crowed at the apex of the branches.

\section{Indumentum}

Perhaps all species of Baccharidinae have vestiture, and species recognized as glabrous or punctate glandular, indeed have some type of indumentum, and in these case obscured by a resin layer. The presence of tufted indumentum is considered highly important into recognize the Baccharidinae, though in several groups of Baccharidinae the tufted indumentum are absent, e. g., Archibaccharis and Lanugothamnus. The twin-trichomes are absent in Baccharis and Baccharidiopsis, but are very common in Archibaccharis, Pingraea, and especially in the new genus Lanugothamnus.

The trichomes of Baccharidinae were investigated by Barroso (1976), Hellwig (1992, 1993), and more recently by Müller (2006). The scheme here proposed is based in these authors, and also Nesom (1994). In some case new names are adopted to types of trichomes undescribed before.

Trichomes uniseriate: (A) Flagellate trichomes, with subterminal cell distinctly larger than the more basal cells, and the terminal cell is much longer and narrower than all other cells, and is usually thin-walled. The terminal cell 
displays equal length or longer than the all basal cells. (B) Flagellate trichomes with curved terminal cells, and the terminal cell displays equal length or shorter than the all basal cells. (C) Flagellate trichomes with branched or arbuscularly branched terminal cell. (D) Filiform trichome, with subterminal cell distinctly larger than the more basal cells, or sub equal, and terminal cell distinctly longer and flexible, often winding. (E) Uniserite trichomes with tick-walled terminal cell, the terminal cell displays equal length or longer than the all basal cells. (F) Uniseriate trichomes with tick-walled and forked or branched terminal cell. (G) Uniseriate trichomes with oblong terminal cell or clavate (Figure 1A-G).

Trichomes biseriate: $(\mathrm{H})$ Glandular, with terminal vesicular cell, and oil secretory, with the typically orange or dark lumen. (I) nonglandular, without terminal vesicular cell, and with vitreous lumen (Figure 1H, I).

Pedestal trichomes: (J) Trichomes with tick-walled cells, composed of several arched epidermal cells and seemingly multiseriate basally and uniseriate in almost all length, ending in a acute terminal cell (often curved). (K) Biseriate pedestal trichomes with a glandular apex (Figure 1J, K).

Twin-trichomes: (L) Twin-trichomes with short basal cells, and very longer terminal cells. (M) Twin-trichomes with short basal cells, median cells more or less longer and terminal cells slight longer than the median cells and frequently divergent apically. In some group of species the twin-trichomes show a basal cell with orange lumen and longer terminal cells (Figure 1L, M).

Tufted trichomes: A complex of trichomes, composed by uniseriate trichomes (often types A, B, and D) and biseriate trichomes (often type I) with adjoining basal cells (Figure 1A, B, D, I).

The tufted trichomes are exclusively found in Baccharidinae, but in several groups are completely absent.

\section{Capitula}

The capitula in almost all species of Baccharidinae are discoid, radiate capitula are found only in functionally staminate capitula of species of Heterothalamus and Baccharis dubia.

Capitulum sex: The distribution of capitula sexes was considered crucial to distinguish the genera of Baccharinae in the past. Actually is considered as a secondary attribute (Nesom 1988a, Nesom 1988b, Müller 2006). In Archibaccharis the pistillate capitula show a single or few central staminate flowers, when the staminate capitula have only staminate flowers (rarely with few neutral flowers). In Pingraea the pistillate and staminate capitula display only pistillate and staminate flowers, respectively, but exceptions occur in some monoecius species, which the capitula show few central staminate flowers and several pistillate flowers surrounded the central flowers. In Heterothalamus the functionally staminate capitula display radial neutral or pistillate flowers, and the pistillate capitula have only pistillate flowers. Finally, all species of Baccharis show discoid capitula with homogomous flowers.

Capitulum shape and number of flowers: Capitulum shape varies from narrowly cylindrical to hemispheric or cup-shaped. The pistillate involucre are relatively narrower than staminate involucres of the same species, and in some species of Baccharis, e.g., for $B$. minutiflora and $B$. parvidentata, the pistillate capitula have a single flower, and the staminate capitula have two or more flowers, while in Heterothalamus alienus the pistillate capitula have up to 300 flowers, and the staminate capitula less than 100 flowers, and in Stephananthus junceus the number of flowers in pistillate capitula reaches 800 flowers, while in the staminate capitula is less than 200 flowers. But, in the majority of species of the subtribe Baccharidinae the number of flowers range is among 25-100 flowers. From staminate capitula 

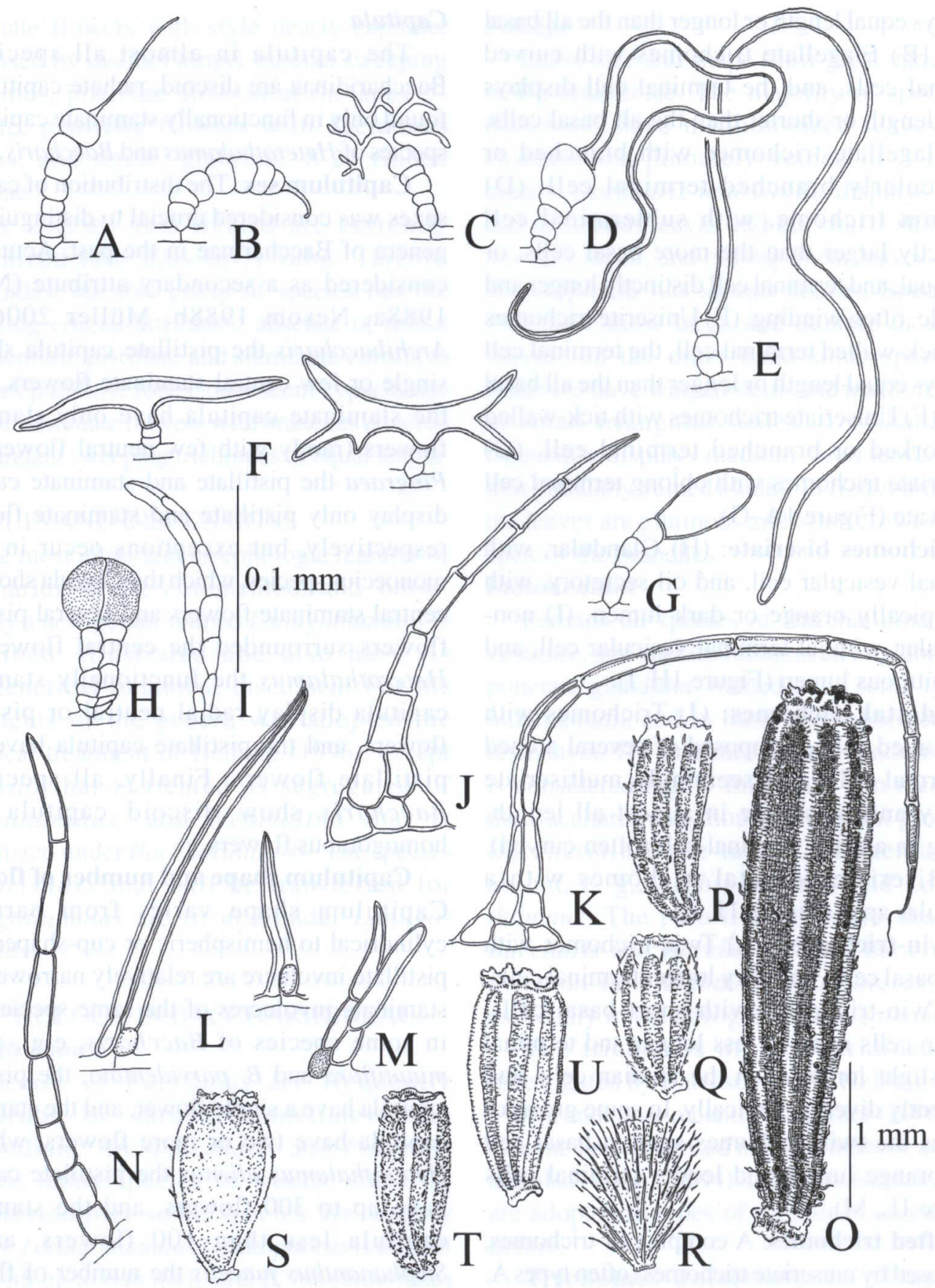

FIGURE 1 - Trichomes in Baccharidinae (A-N). A-C, Flagellate trichomes of Baccharis papillosa Rusby (A-B) and Pingraea sp. (C). D-G, uniseriate trichomes of Baccharis erioclada (D), Baccharis phylicoides Kunth (E), Baccharis uncinella DC. (F), and Heterothalamulopsis wagenitzii (F. H. Hellw.) Deble. (G). H-I, Biseriate trichomes of Lanugothamnus pluricapitulatus Deble. J-K, pedestal trichomes of Baccharis ibitipocensis (J), and Archibaccharis hieracifolia Heering (K). L-M, Twin trichomes of Lanugothamnus Gibertii (L), L. helichrysoides (DC.) Deble (L, right). $\mathrm{N}$, Uniseriate trichome of Baccharidiopsis sp. Cypselae in Baccharidinae (O-U). O, Baccharidiopsis sp. $\mathrm{P}$, Lanugothamnus curitybensis (Heering ex Malme) Deble. Q, Pingraea sp., R, Lanugothamnus leucopappus (DC.) Deble. S Archibaccharis hieracifolia Heering. T, Lanugothamnus ochraceus (Spreng.) Deble. U, Baccharis linearifolia (Lam.) Pers. Scale bar between F and I from A-N. Scale bar near O from O-U. 
the range vary but at a narrower range than the pistillate capitula. The variation pistillate/ staminate ratio per capitulum is not related with generical relationships as proposed by Hellwig (1993, 1996); despite in several species of Pingraea may be a tendency to pistillate/ staminate ratio per capitulum of three or more.

\section{Involucrum}

Involucrum shape varies from narrowly cylindrical or turbinate to hemispheric. Pistillate involucres are often relatively narrower than staminate involucres of the same species. Species of Baccharis have involucres cylindrical to campanulate, but in Baccharis reticularioides the pistillate involucre is urceolate, while in $B$. salzmanii and in several other Brazilian species is turbinate. In Heterothalamus rupestris the staminate involucre is campanulate and the pistillate involucre is nearly globose. Pistillate and staminate involucres of about equal size and shape are found in some species of Baccharis, e. g., Baccharis pampeana, and also in Lanugothamnus curitybensis and L. chionolaenoides.

\section{Phyllaries}

The phyllaries are imbricate and helically arranged in 2-14 series. Pistillate involucres are often with more phyllaries series than the staminate involucres of the same species.

Texture: Almost all species of Baccharidinae have papiraceous phyllaries, some groups display cartilaginous thickened phyllaries, e.g., Lanugothamnus.

General coloration of the phyllaries: Typically the phyllaries are greenish-brown colored, with a medial brown strip. Stephananthus junceus, some species of Baccharidiopsis, and species of Lanugothamnus have apically purplish phyllaries.

Margin of the phyllaries: The margin of the phyllaries can be entire, scariose, fimbriate or dentate, sometimes with biseriate trichomes associated.

Dorsum of the phyllaries: The dorsum of the phyllaries is typically more thickened than the margin, and often displays glandular trichomes and/or filiform trichomes. In Baccharis phylicoides the outermost phyllaries are clothed by filiform trichomes with terminal cell rigid, with thickened wall, Lanugothamnus artemisioides have phyllaries with long filiform trichomes, while in the majority of species of Baccharis the dorsum of the phyllaries are glutinous by presence of glandular trichomes.

Venation of the phyllaries: The majority of Baccharidinae have a central vein, but some species display parallel veins or pinnately branched vein.

\section{Receptacle}

In many species the receptacle is convex or conical, most rarely flat. The point of insertion of the flowers is often well-marked, and commonly presents fimbrils or trichomes.

Paleae: The presence of paleae in receptacle of pistillate capitula was crucial to distinguish the genera Pseudobaccharis and Psila in the past (Cabrera 1944, 1955); however in the course of the time this morphologic feature was considered as secondary attribute (Cuatrecasas, 1967, Cabrera 1978, Müller 2006). The paleae occur only in pistillate capitula and can show the following attributes: (A) persistent and folded, e.g., Heterothalamus alienus, Heterothalamulopsis Wagenitzii, Baccharis dubia; (B) flat and persistent, e.g., Heterothalamus psiadioides, $H$. rupestris; (C) folded and deciduous, e.g., Baccharis boliviensis; (D) Flat and deciduous, e.g., all species of Baccharis sect. Oblongifoliae, Pingraea trinervis, and $P$. rhexioides (Figure $2 \mathrm{~F}-\mathrm{I}$ ).

Receptacular Fimbrils: In several species of Baccharis and Baccharidiopsis in the point of intersection of the flowers and the receptacle, occurs a rather prolonged receptacular honeycomb tooth.

Indumentum of the receptacle: Whitish filiform trichomes are often in Lanugothamnus, uniseriate trichomes with clavate terminal cell occur in Heterothalamulopsis Wagenitzii, while in species of Baccharis the receptacle is glabrous 
or with uniseriate or biseriate trichomes, very rare glandular trichomes (fide Müller 2006: 48).

\section{Flowers}

The shape of flowers of Baccharidinae is applicable to distinguish genera and groups. Staminate flowers are often relatively homogeneous than pistillate flowers, but exception can be found, e.g., Lanugothamnus montevidensis, and in several species of Baccharidiopsis.

Shape of flowers: The pistillate flowers of Baccharidinae can be filiform or tubular, apically truncated, ligulate or 5-dentate, and usually with less than $10 \mathrm{~mm}$ long. Baccharis is characterized by tubular at the apex 5-dentate corolla, Pingraea and Baccharidiopsis, in its turn, included species with tubular at the apex truncate corolla. Ligulate corolla are found in some species of Pingraea, almost all species of Archibaccharis, Baccharis dubia group, Baccharis boliviensis, all species of Heterothalamus and Heterothalamulopsis Wagenitzii. In Lanugothamnus and Baccharis thymifolia the pistillate corolla shows papillae apically; furthermore species of Lanugothamnus, e.g., Lanugothamnus ochraceus, have a tendency to produce short and thickened pistillate corolla (Figure $2 \mathrm{~J}-\mathrm{O}$ ). The staminate flower consists of a long, cylindric tube and a limb that is divided in five teeth or lobes. The species of Baccharis have lanceolate or oblonglanceolate lobes; while in all species of Heterothalamus and Lanugothamnus montevidensis the corolla has more or less triangular, short, and erect teeth.

Discolour flowers: The flowers of almost all species of Baccharidinae display corolla not discolorous, and often are stramineous, whitecream or greenish-cream colored, and apically pink or purplish. Exception is found in Heterothalamus that have pistillate flowers with corolla greenishyellow in pistillate capitula and pistillate flowers (often neutral) yellow or golden-yellow in functionally staminate capitula.
Corolla trichomes: Baccharis displays pistillate corolla with scattered biseriate trichomes and staminate corolla with trichomes concentrated in the apex of the tube. In several species of Pingraea the pistillate corolla is crowed by uniseriate trichomes apically.

Corolla papillae: Papillae are exclusively found in corolla of pistillate and staminate flowers of all species of Lanugothamnus, and Baccharis thymifolia. The papillae are distributed apically, on dorsal surface of the lobes.

\section{Style}

The styles of pistillate flowers are rather homogeneous in Baccharis, being mostly lanceolate or linear-lanceolate branches, but exceptions occur, e.g., style with deltate branches is found in Baccharis crassipappa and B. myricifolia. In Heterothalamus the style branches are distinctly short, while in some species of Lanugothamnus it is deltate, and in Baccharis dubia and B. macrophylla the style branches are deltate or ovate and slightly asymmetrical, and finally in Baccharis thymifolia the style branches is nearly obovate (Figure 2S-U). The style of functionally staminate flowers are heterogeneous and since Heering (1904) has been used to distinguish groups in Baccharidinae. Hellwig (1990) provided differences, including the length and abundance of sweeping trichomes and branches shape.

Distribution of stigmatic area: The styles of pistillate flowers have the stigmatic lines along the margins. In the style of functionally staminate flowers the stigmatic area are absent.

Distribution of sweeping trichomes and shape of style branches: Sweeping trichomes are exclusively found in style of functionally staminate flowers and can be interpreted as crucial to distinguish genera, e.g., all species of Baccharis display nearly capitate and attached (sometimes partially free apically) style branches, and median sweeping trichomes distinctly longer than the basal and terminal ones. Pingraea and Baccharidiopsis have 
lanceolate style branches and sweeping trichomes of about equal length, often concentrated distally, while in Lanugothamnus the sweeping trichomes are of about equal length and abundant in the whole extension (Figure $2 \mathrm{P}-\mathrm{R}$ ).

\section{Stamens}

The stamens are typical of the majority groups of Astereae, and the anthers are oblong or nearly rectangular, apically nearly triangular, and basally rounded or rarely slightly acute, e.g., Baccharis dubia.

Pollen morphology: The pollen grains are tricolporate and spinose (Aster type) with few variations within genera.

\section{Cypsela}

The cypselae in Baccharis are shorter than $3 \mathrm{~mm}$, in Pingraea and Heterothalamus often shorter than $1 \mathrm{~mm}$, on the other hand in Baccharidiopsis are usually 3-10 mm long, and the apical portion is visible in the capitulum at maturity (Figure $1 \mathrm{O}-\mathrm{U}$ ).

Shape of cypsela: The obovate or elliptic cypselae with carpopodium few developed are frequent in several species of Baccharidinae.

Length of cypsela: Cypselae are typically small or medium-sized, with less than $3 \mathrm{~mm}$ long, except by species of Baccharidiopsis that have cypselae relative large, with up to $10 \mathrm{~mm}$ long.

General coloration of cypsela: The cypselae are usually stramineous or brown, variations are observed only in species of Baccharidiopsis that have dark-purple cypselae.

Cypsela epidermis: The cypsela epidermis may be important to distinguish groups, principally within the genus Baccharis. Folded cypselae are common in several species of Baccharis and Baccharidiopsis, but Brazilian species of Baccharidiopsis, e.g. Baccharidiopsis pohlii, have smooth cypselae. Papillose cypsela is frequently found in Pingraea, and Lanugothamnus, when the majority species of Archibaccharis and Pingraea have smooth cypselae.
Trichomes of cypsela: Baccharis, Heterothalamus, and Heterothalamulopsis display glabrous cypselae. Twin-trichomes are present in cypselae of Pingraea, Archibaccharis, Baccharis sect. Oblongifoliae, Baccharis dubia group, and Lanugothamnus, on the other hand the twin-trichomes are completely absent in Baccharidiopsis. Flagellate trichomes occur in all species of Baccharidiopsis, but always lack in other genera. Glandular trichomes are common in several groups, e.g., Pingraea, Archibaccharis, and Lanugothamnus.

\section{Pappus}

Staminate flowers have pappus uniseriate and often with some additional bristles, pappus biseriate is extremely rare, e.g., Baccharis camporum and B. trineura. The pappus of pistillate flowers consist of more or less straight bristles or rarely pectinate setae, which are arranged in the follows: (A) biseriate or in several series, free basally, e.g., several species of Baccharis; (B) biseriate or in several series, fused in a basal ring at the base, e.g., Lanugothamnus montevidensis, some species of Baccharis; (C) uniseriate and free basally, e.g., all species of Heterothalamus, (D) uniseriate and fused in a basal ring, e.g., several species of Pingraea and Archibaccharis; (E) pectinate setae, exclusively in Heterothalamulopsis Wagenitzii (Figure 2A-E).

Pappus bristles: Almost all species of Baccharidinae have pappus composed by scabrid bristles, and the pappus of pistillate flowers is narrower when compared with the pappus of staminate flowers of the same species. The species of Heterothalamus have pappus rigid and resembles the shape of the pappus of several genera of Hintheruberinae.

Pappus scales or setae: Pappus composed by pectinate setae is found only in the pistillate flowers of Heterothalamulopsis Wagenitzii. This morphologic feature did not mentioned by Deble et al. (2004) in the protologue of the new genus, but is detailed illustrated and have your importance investigated (Deble, unp. data). 


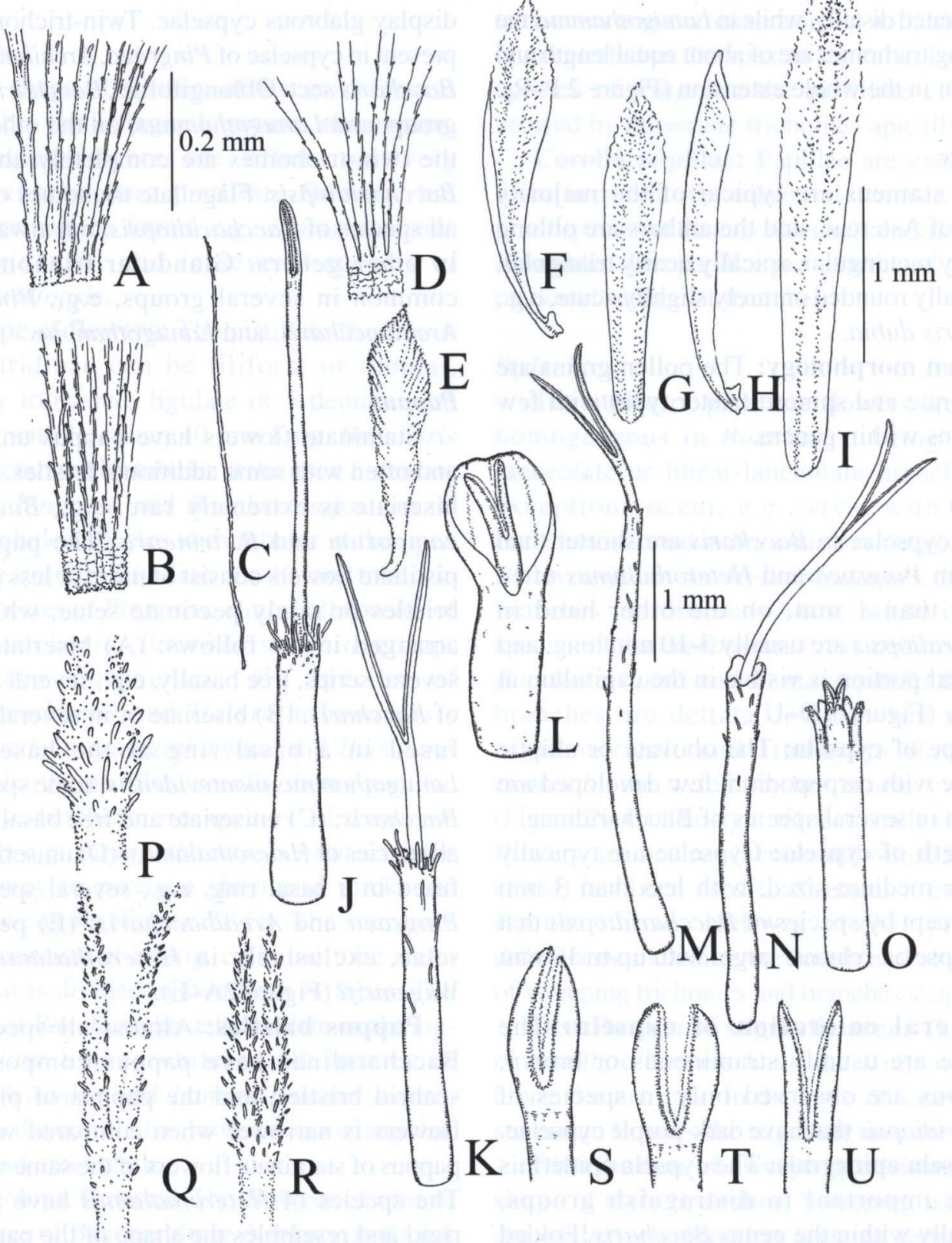

FIGURE 2 - Pappus in Baccharidinae (A-E). A, Baccharis linearifolia (Lam.) Pers. B, Lanugothamnus ochraceus (Spreng.) Deble. C, Heterothalamus alienus (Spreng.) O. Kuntze. D, Pingraea viscosa (Ruiz \& Pav.) F. H. Hellw. E, Heterothalamulopsis wagenitzii (F. H. Hellw.) Deble. Paleae in Baccharidinae (F-I). F, Heterothalamulopsis wagenitzii (F. H. Hellw.) Deble. G, Heterothalamus rupestris Deble, A. S. Oliveira \& Marchiori. H, Baccharis boliviensis (Weddel) Cabrera. I, Baccharis grandimucronata Malag. Pistillate corolla in Baccharidinae (J-O). J, Pingraea viscosa (Ruiz \& Pav.) F. H. Hellw. K, Baccharidiopsis sp. L, Heterothalamulopsis wagenitzii (F. H. Hellw.) Deble. M, Baccharis linearifolia (Lam.) Pers. N, Pingraea crispa (Spreng.) F. H. Hellw. O, Lanugothamnus erigeroides (DC.) Deble. Style of staminate flowers (P-R). P, Baccharis dracunculifolia DC. Q, Pingraea sp. R, Lanugothamnus gnaphalioides (Spreng.) Deble. Style of pistillate flowers (P-R). S, Baccharis dubia Deble \& A. S. Oliveira. T, Baccharis thymifolia Hook. \& Arn., U, Lanugothamnus montevidensis (Spreng.) Deble subsp. montevidensis. 
Fusion of pappus bristles: Pistillate flowers can show pistillate pappus fused in a basal ring, e.g., Pingraea, Lanugothamnus, but in the majority of the species the pappus is free or partially fused by few cells at base, e.g., species of Baccharis.

Shape of apical pappus cells: In the majority of species of Baccharis the pappus of staminate flowers is plumose or thickened at the apex, and the cells are patent and apically clavate; however all species of Heterothalumus, and several species of Lanugothamnus have pappus of staminate flowers narrowed at the apex. The pappus of pistillate flowers is frequently narrowed at the apex.

Persistence at cypsela maturity: In all species of Baccharis the pappus of pistillate flowers is deciduous at cypsela maturity; on the other hand the genera Pingraea, Lanugothamnus, and Baccharidiopsis have pappus persistent. In some groups the pappus is elongated at cypsela maturity, e.g., several species of Baccharis, all species of Baccharidiopsis, but in Pingraea and in Archibaccharis the pistillate flowers have pappus not elongated at cypsela maturity.

\section{Cypselae dispersion}

The anemochory is the most common in Baccharidinae. All species of the group of species with persistent pappus are anemochoric, but also several species of Baccharis the cypselae also have dispersion by anemochory. The unusual zoochory by bird dispersion was observed in Heterothalamus. Species with relative large cypselae, e.g., many species of Baccharidiopsis the cypselae germinates near the mother plant. This characteristic is also reported to some species of Baccharis. It should be noted that in the majority of species the cypselae dispersion was not investigated.

\section{DESCRIPTION OF LANUGOTHAMNUS}

\section{Lanugothamnus Deble, gen. nov.}

Plantae dioicae. Frutex vel Suffrutex (rare arbor parva), aliqui xylopodiferis vel cum ramis rhizomatis; ramis teretibus, pubescentis (rare glabrescentis), pilis filiformis, glanduliferis et hirtellis vestitis. Foliis parviis vel mediocris vel magnis, alternis, sessilis vel petiolatis, saepe discoloris; laminis dense pilosis vel glutinosis, membranaceis ad chartaceis (rare coriaceis), peninerviis vel retinervis (rare trinervis), lanuginosis (rare glabrescentis), margine integris, crenatis vel dentatis, saepe revolutis. Capitulis is pyramidalis, racemiformis vel corimbiformis paniculis terminalibus disposittis. Capitulum staminatorum campanulatum vel hemisphericum; phyllaris 2-6 seriatis, cartilaginosis, margine hyalinis, dorsum crassum, saepe lanuginosum; receptaculis cum pilis biseriatis et uniseriatis flagellatis munitis; paleae absenti. Floribus isomorphis, androgyna sed gynaeceo abortivo staminatis; pallide lutei ad eburni, apice aurantiacis, albidis ad purpureis; corollis tubulosis, limbo ampliato, breve pentadentato ad pentassecto, cum pilis biseriatis conspersis et apice papillosis. Stylus filiformibus, apice bifidus; rami styli deltati ad lanceolati, pilis colectoribus apicem versus dense munitus; antherae basi rotundae. Pappus unisseriatus, setae pappi barbellatis, non accrescentes, persistentes. Capitulum pistillatorum oblongum, campanulatum vel hemisphericum; phyllaris 2-6 seriatis, cartilaginosis, dorsum crassum, saepe lanuginosum; receptaculis cum pilis biseriatis et uniseriatis flagellatis munitis; paleae absenti. Flores isomorphi, pistillatis, straminei vel eburni, apice albidis, aurantiacis vel purpureis; corollis late tubulosis ad filiformis, cum pilis biseriatis conspersis et apice 5-dentatis, papillosis. Stylus filiformibus, apice bifidus; rami styli deltati ad lanceolati, papillis stigmatis apicem versus in duabus lineis marginalibus apicem versus concurrentes. Pappus bisseriatus (aliqui uniseriatus), setae pappi barbellatis, accrescentes (rare non accrescentes), persistentes (rare caducae). Cypselae compressae vel angulatae (rare teretiae), 3-11 nervatae, cum pilis geminis conspersis vel abundantis, saepe pilis biseriatis glandulosis et non glandulosis vestitis.

Typus generi: Lanugothamnus helichrysoides (DC.) Deble [= Baccharis helichrysoides DC.]

Dioecious plants. Prostrate or erect subshrubs or shrubs, rarely small tree, sometimes with xylopodium or rhizome; stems usually clothe by dense indumentum. Indumentum mostly of uniseriate trichomes (type A, D, and E), biseriate trichomes (type $\mathrm{H}$, and I), and pedestal trichomes associated (type J). Leaves small to large, alternate, sessile or petiolate, frequently discolorous; leaf blades thin or coriaceous, pinnately veined, reticulum veined, 3-veined or seemingly veinless or 1-veined, sparse or 
densely clothed by trichomes, margin entire, crenulate or dentate flat or revolute. Capitula pedunculate, in terminal pyramidal capitulescence, racemiform or corymbiform capitulescence. Staminate capitula hemispheric or cup-shaped. Involucre phyllaries in 2-6 series, cartilaginous, margin membranaceous, scariose, centrally thickened, mostly dense clothed by uniseriate trichomes on dorsum (type $\mathrm{D}$, and $\mathrm{E}$ ), often together with biseriate trichomes (type $\mathrm{H}$, and I). Receptacle convex, flat or slightly conical, dense or sparse clothed by uniseriate trichomes (mostly type A, but also type E); and biseriate trichomes (type I). Staminate flowers white-cream at apex cream, orange or purplish, base tubular at apex dilated with five papillose lobes; style not or exceeding the corolla, apex divided into broadly lanceolate or deltate branches, densely covered by sweeping trichomes; sweeping trichomes of about equal length. Anthers at base rounded; pappus bristles 1-seriate (rare with additional bristles), persistent, at the apex attenuate or most rarely plumose. Abortive cypselae compressed, with 2-6 inconspicuous ribs, with twin-trichomes and/or glandular trichomes scattered. Pistillate capitula oblong, campanulate or hemispheric; involucral bracts in 2-6 series; receptacle flat or slightly conical, with uniseriate trichomes, and biseriate trichomes (of the same types of the trichomes of receptacle of staminate capitula). Receptacle without paleae. Pistillate flowers white-cream at the apex white cream, orange or purple; corolla tubular-filiform or broadly tubular, at apex denticulate, papillose; style not or exceeding the corolla, apex divided into deltate to lanceolate branches, stigmatic papillae on marginal line; pappus bristles 2seriate (sometimes 1-seriate), fused in a basal ring (rarely free), persistent (rarely deciduous), at apex attenuate, not or strongly elongated at cypsela maturity. Cypselae angulated to laterally compressed (rarely terete), 3-11-ribbed, few or densely clothe by twin-trichomes (type L, and $\mathrm{M})$, and often with biseriate trichomes scattered (type $\mathrm{H}$ and $\mathrm{C}$ ).
Geographic distribution: Lanugothamnus is a South America genus with 20 species, found in eastern and southeastern Brazil, Uruguay, Paraguay, Bolivia, and center and northern Argentina. The majority species are found in Brazil and Uruguay.

Etymology: From the Latin lanugus meaning lanose and thamnus that mean bushy, and referring to indumentum of the majority species of the genus.

\section{INFRAGENERICAL TREATMENT}

The genus Lanugothamnus can be segregated in four subgenera, and two sections, according with the following features: trichomes of receptacle, type of twin-trichomes of cypselae, cypselae shape and ribs, pappus features, habit, leaf morphology, and capitulescence. The infrageneric treatment is summarized in the table 1.

\section{A. Lanugothamnus Deble subg. Lanugo- thamnus}

= Baccharis sect. Canescentes Giuliano, Novon 15 (4): 535. 2005. Type: Baccharis helichrysoides DC.

Lanugothamnus subg. Lanugothamnus is characterized by grayish or whitish indumentum on stems, leaves and capitula, discolorous leaves, corymbiform capitulescence, and compressed, 3-5 ribbed cypselae, clothed by acute twin-trichomes. Lanugothamnus subg. Lanugothamnus includes eight species from southern Brazil, Uruguay, northeast Argentina and Paraguay.

Lanugothamnus Deble subg. Lanugothamnus sect. Lanugothamnus

Cypselae non sericeous pubescent, twintrichomes on ribs concentrate. Four species (three species are subsequently summarized, and a new species is described in the page 20).

\section{List of Species}

1. Lanugothamnus helichrysoides (DC.) Deble, comb. nov. Basionym: Baccharis helichrysoides DC., Prodr. 5: 415. 1836. Type: BRAZIL. Rio Grande do Sul/São Paulo: "in Brasiliae prov. Rio-Grande et Sancti-Pauli.... (v. 
s. + et $\sigma^{\prime}$ in h. Mus. reg. Par. à Mus. imp. Bras. sub n. 811 et 492 miss.)", \& \& O', F. Sellow d2013 (lectotype P, P00468143 photo!, designated by Malagarriga 1958: 284, duplicate: G-DC, G-DC 00200392 photo!).

= Baccharis lanuginosa Gardner, London J. Bot 7: 82. 1848. Type: BRAZIL. Minas Gerais: "Dry bushy places between Villa do Principe and Cocaes", September 1840, , G. Gardner 4900/1 (holotype BM not seen).

2. Lanugothamnus patens (Baker) Deble, comb. nov. Basionym: Baccharis patens Baker, Fl. Bras. (Martius) 6 (3): 52. 1882. Type: URUGUAY. Montevideo: "prope Montevideo: Sello n. 463! 729!” +, Sellow 463 (lectotype K here designated, K000221906 photo!).

= Baccharis squarrosa Baker, Fl. Bras. (Martius) 6 (3): 50. 1882 [non Kunth 1818]. Type: URUGUAY. "in campis et rupestribus ad Maldonado: Capt. King!; prope Montevideo: Sello n. 2808! 2924!; prope Las Minas in fissuris rupium: Gibert n. 881!", ๆ, right sheet, King s.n. (lectotype K here designated, K000222091 photo!).

= Baccharis Bakeri Heering, Jahrb. Hamburg. Wiss. Anstalt. 21 (3): 39. 1904. TYPE: Brazil, Rio Grande do Sul, Porto Alegre, "Reineck \& Czermak n. 106. Rio Grande do Sul. Belém Vélho an bebuschten Hängen" pistillate and staminate specimens, 12-IX-1894, Reineck \& Czermak 106 (holotype HBG not seen; isotype P, P00509635 photo!).

3. Lanugothamnus phylicifolius (DC.) Deble, comb. nov. Basionym: Baccharis phylicifolia DC., Prodr. 5: 415. 1836. as "phylicaefolia". Type: BRAZIL. São Paulo: "in Brasiliae prov. Sancti-Pauli. ... (v. s. in h. Mus. reg. Par. à Mus. imp. Bras. sub n. 491 miss.)", ơ, F. Sellow s.n. (holotype P, P00755658 photo!; isotype G-DC, G-DC 00200390 photo!).

Lanugothamnus subg. Lanugothamnus sect. Sericicarpa Deble, sect. nov.

Sectio Lanugothamno subg. Lanugothamno pertinens, sed differt cypselis sericeis, pilis geminis longioribus et abundantibus munitis.

Type: Lanugothamnus leucocephalus (Dusén) Deble

Cypselae sericeous pubescent, densely clothed by twin-trichomes. The section Sericicarpa comprises four species of Southern Brazil and Uruguay.
Etimology: From the Latin sericeus meaning sericeous, and carpus that mean fruit, and referring to sericeous pubescent cypselae.

\section{List of Species}

1. Lanugothamnus Gibertii (Baker) Deble, comb. nov. Basionym: Baccharis Gibertii Baker, Fl. Bras. (Martius) 6 (3): 52. 1882. Type: URUGUAY: "ad Maldonado et Montevideo, ad ripas fluminis S. Lucia: Capt. King! Gibert n. 813 ! 814! Arechavaleta n. 4104! Cunningham!". URUGUAY. Montevideo: Santa Lucia, 1867, pistillate flower, M. E. Gibert 814 (lectotype K, designated by Barroso 1976: 63, K000222026 photo!).

2. Lanugothamnus gnaphalioides (Spreng.) Deble, comb. nov. Bas. Baccharis gnaphalioides Spreng., Syst. Veg. 3: 461. 1826. Type: BRAZIL. Rio Grande do Sul (?): “Ad. fl. magnum Amer. austr. Sello", O' Sellow d585 (holotype P not seen; isotype K, K000221905 photo!, GH, GH00247131photo!).

= Baccharis radicans DC., Prodr. 5: 416. 1836. Type: BRAZIL. Rio Grande do Sul: "in Brasiliae prov. RioGrande... v. s. + in h. Mus. Reg. Par. à Mus. imp. Bras. sub. n. 906 miss.", pistillate flowers, Herb. Imp. Bras. 906 (holotype P, P00755689 photo!; isotype G-DC, G-DC3252 photo!).

$=$ Baccharis psammophila Malme, Kungl. Svenska Vetenskapsakad 12 (2): 70. 1933. Type: BRAZIL. Santa Catarina: Laguna, "24/6 09 (n. 8425). Hab. in arena mobili" Dusen 8425 (holotype S, S-R-597 photo!).

\section{Lanugothamnus leucocephalus (Dusén)} Deble, comb. nov. Basionym: Baccharis leucocephala Dusén, Ark. Bot 15: 24. 1910. Type: BRAZIL. Paraná: Piraquara, "Wächst in Gebüschen; bei Roça nova, den 24. Nov. 1903, (Nr. 2208), und bei Itapirusú, den 17. Nov. 1908", O and O', P. K. H. Dusén 2208 (lectotype S, S10-22317 photo!, designated by Barroso 1976: 62; duplicate R!).

4. Lanugothamnus leucopappus (DC.) Deble, comb. nov. Basionym: Baccharis leucopappa DC., Prodr. 5: 415.1836. Baccharis helichrysoides var. leucopappa (DC.) Baker, Fl. 
Bras. (Martius) 6 (3): 51. 1882. Type: BRAZIL. Rio Grande do Sul: "in prov. Rio-Grande Brasiliae. (h. Mus. imp. Bras. n. 330)",,$+ F$. Sellow 3111 (holotype P, P00755454 photo!; isotypes G-DC, G-DC 00200391 photo!, P, P00755455 photo!).

\section{B. Lanugothamnus subg. Toxicothamnus}

\section{Deble, subgen. nov.}

= Baccharis sect. Coridifoliae Giuliano, Ann. Missouri Bot. Gard. 98 (3): 339. 2011. Type: Lanugothamnus montevidensis (Spreng.) Deble [= Baccharis coridifolia DC.]

Suffrutex xylopodiferus, aliqui rhizomatosus, ramis e base leviter lignosis (rare frutex). Folia linearia vel oblongo-linearia, concolora vel discolora. Capitulescentia racemiformis. Capitulum pistillatorum oblongum vel campanulatum, receptaculis cum sparse pilis uniseriatis flagelliformis et biseriatis non secretoris munitis. Floribus pistillatorum crasse tubulosum. Capitulum staminatorum hemisphericum. Flores staminatorum apice breviter lobatum.

Typus subgeneri: Lanugothamnus montevidensis (Spreng.) Deble [= Eupatorium montevidense Spreng., non Baccharis montevidensis Spreng.]

Lanugothamnus subgenus Toxicothamnus is characterized by racemiform capitulescence, seemingly glabrous with few uniseriate trichomes (type A) and biseriate trichomes (type I) on receptacle scattered, broad tubular pistillate corolla, and style not or slightly exceeding at the corolla. Giuliano \& Freire (2011) included the pistillate pappus 2-seriate and elongated at cypsela maturity as important morphologic feature to distinguish the sections Coridifoliae (now subgenus Toxicothamnus, under $\mathrm{La}$ nugothamnus) and Tarchonanthoides (now subgenus Tarchonanthoides, under Lanugothamnus), but the pappus of $L$. scabrifolius and the new species $L$. pluricapitulatus, described in this paper, have bristles 1-seriate, not or slightly elongated at cypsela maturity. On the other hand, both subgenera can be easy segregated by habit, pistillate corolla features, and leaf-shape (Table 1). The subgenus encompasses eight species and one subspecies occurring in Brazil, Uruguay, Paraguay, Bolivia, and center and northern Argentina.

Etymology: From the Latin toxicus meaning poisonous and thamnus that mean bushy, and referring to chemical property of some species of the subgenus, e.g., Lanugothamnus artemisioides and L. montevidensis.

\section{Lanugothamnus Deble subg. Toxico-} thamnus Deble sect. Toxicothamnus

Subshrubs with xylopodium and rhizome, stems weakly woody. Pappus of pistillate flowers biseriate, elongated at cypsela maturity. Six species and one subspecies, with range of geographical distribution equal of the subgenus.

\section{List of Species}

1. Lanugothamnus albolanosus (A. S. Oliveira \& Deble) Deble, comb. nov. Basionym: Baccharis albolanosa A. S. Oliveira \& Deble, Balduinia 9: 4. 2006. Type: BRAZIL. Rio Grande do Sul: São Francisco de Assis, "RS 241, estrada de chão entre São Francisco de Assis e Manoel Viana, em solo arenoso", + and $\sigma^{\prime \prime}, 27-$ II- 2006, L. P. Deble \& A. S. de Oliveira 5109 (holotype MBM!; isotypes CTES!, HDCF!, SI!).

2. Lanugothamnus artemisioides (Hook. \& Arn.) Deble, comb. nov. Basionym: Baccharis artemisioides Hook. \& Arn. J. Bot (Hooker) 3: 41. 1841. Type: ARGENTINA, Buenos Aires, Córdoba, San Luis: "Between Rio de los Novillos and el Rio Quinto, province of San Luis. Dr Gillies (n. 185.) Salt Plains of Bahia Blanca, lat. $40^{\circ}$. in N. Patagonia, and in high and dry places of Cordova. Tweedie (n. 1126.)". between Río Chorillos and Río Quinto,,$+ J$. Gillies 185 (lectotype K here designated, K000222002 photo!).

3. Lanugothamnus erigeroides (DC.) Deble, comb. nov. Basionym: Baccharis erigeroides DC., Prodr. 5: 418. 1836. Type: BRAZIL. São Paulo: "in campis editis prov. Sancti-Pauli legit cl. Lund... v. s. comm. à cl. Lund [p. excl. n.

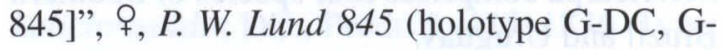
DC 00136722 photo! 
= Baccharis puberula DC., Prodr. 5: 401. 1836.Type: BRAZIL. São Paulo: "in Brasiliae prov. Sancti-Pauli ... (v.s. + in h. Mus. reg. Par. à Mus. imp. Bras. sub n. 515 miss.) ",, , F. Sellow s.n. (holotype P, P00755577 photo! Isotype G-DC, G-DC3250 photo!).

= Baccharis erigeroides var. Dusenii Heering, Ark. Bot. 9: 23. 1910. Type: BRAZIL. Paraná: Ponta Grossa, Capão Grande "Gesammelt auf den Campos bei Capão grande am 18. Dez. 1903 (Nr. 2766), und bei Capivari am 21. Okt. 1908"., O', P. K. H. Dusén 2766 (lectotype R!, designated by Barroso 1976: 55).

4. Lanugothamnus montevidensis (Spreng.) Deble, comb. nov. Basionym: Eupatorium montevidense Spreng., Syst. Veg. 16, 3: 417. 1826. Type: URUGUAY. Montevideo, "Monte Video. Sello" o, F. Sellow s.n. (holotype P, P00755549 photo!). non Baccharis montevidensis Spreng. [= Vernonanthura montevidensis (Spreng.) $\mathrm{H}$. Rob.].

$=$ Baccharis coridifolia DC., Prodr. 5: 422. 1836. Type: BRAZIL. Rio Grande do Sul, São Paulo: "in Brasiliae prov. Rio-Grande et fortè Sancti-Pauli. ... (v. s. in h. Mus. reg. Par. à Mus. Imp. Bras. sub n. $810,826,837,855$ et fortè 510 miss.)" F. Sellow d1893 (lectotype P, P00755558 photo!, designated by Barroso 1976: 56; duplicates G-DC, R!).

\subsection{Lanugothamnus montevidensis} (Spreng.) Deble subsp. bicolor (Joch. Müller) Deble, comb. nov. Basionym: Baccharis coridifolia DC. subsp. bicolor Joch. Müller, Syst. Bot. Monographs 76: 276. 2006. Type: BOLIVIA. Cochabamba: Prov. Ayopaya, Independencia-Kami, 3670m" 29-XI-1981, Beck 7467 (Holotype JE, JE00005245 photo!; isotypes: G, not seen, US, US00901696 photo!, USZ not seen).

5. Lanugothamnus ochraceus (Spreng.) Deble, comb. nov. Basionym: Baccharis ochracea Spreng. Syst. Veg. 16, 3: 460. Type: URUGUAY. Montevideo: "Monte Video. Sello", O', F. Sellow d477 (holotype P, P00755681 photo!; isotypes K, K000221891 photo!, P, P00755680 photo!).

= Baccharis velutina DC., Prodr. 5: 415. 1836. Type: BRAZIL. Rio Grande do Sul: "in Brasiliae prov. RioGrande. ... (v. s. in h. Mus. reg. Par. à Mus. Imp. Bras. O" sub n. 995 , + sub 819 miss.)", O", F. Sellow d1978 (lectotype P, P00755682 photo!, designated by Malagarriga 1958: 288; duplicates K, K0222047 photo!, NY, NY00162282 photo!, P, P00755680 photo!).
6. Lanugothamnus suberectifolius (A. S. Oliveira \& Deble) Deble, comb. nov. Basionym: Baccharis suberectifolia A. S. Oliveira \& Deble, Bonplandia 17 (1): 22. 2008. Type: BRAZIL. Paraná: Palmeira, "Rod. BR-277, rio Papagaios, campo limpo, ereta, capítulos alvescentes", 11II-1988, \&, G. Hatschbach \& S. Ginzbarg 51875 (holotype MBM! Isotype CTES!).

\section{Lanugothamnus subg. Toxicothamnus} sect. Pluricephala Deble, sect. nov.

Sectio Lanugothamno subg. Toxicothamno pertinens, sed pappo florum pistillatorum uniseriato, non acrescenti differt.

Type: Lanugothamnus scabrifolius (G. Heiden) Deble.

Shrubs, pistillate flowers with pappus 1seriate, not elongated (slightly) at cypsela maturity. Two species highly endemic in southern Brazil (one species is subsequently summarized, and a new species is described in the page 16).

Etymology: From the Latin pluri meaning many and cephala that mean capitulum, and referring to number of capitula of the species.

\section{List of species}

1. Lanugothamnus scabrifolius (G. Heiden) Deble, comb. nov., Baccharis scabrifolia G. Heiden, Bradea 13: 6. 2008 [16 June 2008]. TYPE: Brazil, Rio Grande do Sul, "Taimbesinho p. São Francisco de Paula [Cambará do Sul, Itaimbezinho], 7 Feb. 1941, O'", Rambo 4392 (holotype PACA!).

= Baccharis multipaniculata A. S. Oliveira \& Deble, Bonplandia 17 (1): 18.2008 [August 2008]. TYPE: Brazil, Santa Catarina, Curitibanos, "no campo,,+ 900 m s.m., 22II-1962", Reitz \& Klein 12222 (holotype HBR!). syn. nov.

\section{Lanugothamnus subg. Curitybenses} (Giuliano) Deble, comb. et stat. nov. Basionym: Baccharis sect. Curitybenses Giuliano, Novon 15: 536. 2005. Type: Lanugothamnus curitybensis (Heering ex Malme) Deble [= Baccharis curitybensis Heering ex Malme]. . 
Lanugothamus subg. Curitybenses is characterized by ferrugineous indumentum, terete, 9-11-ribbed cypselae and pappus of pistillate flowers not fused in a basal ring, easy deciduous. The subgenus comprises only two species; both endemic in southern Brazil (see also Giuliano 2005, Falkenberg \& Deble 2010).

\section{List of species:}

1. Lanugothamnus chionolaenoides (D. B. Falkenb. \& Deble) Deble, comb. nov. Basionym: Baccharis chionolaenoides D. B. Falkenb. \& Deble, Darwiniana 48 (1): 64. 2010. Type: BRAZIL. Santa Catarina: Urubici, "extremo sul do topo do Morro da Igreja, pouco além da área cercada pelo CINDACTA", 6-XII-1996, $9, D$. B. Falkenberg 8961 (holotype FLOR!; isotypes CTES!, MBM!, SI!, UEC).

2. Lanugothamnus curitybensis (Heering $\mathrm{ex}$ Malme) Deble, comb. nov. Basionym: Baccharis curitybensis Heering ex Malme, Kungl. Svenska Vetenskapsakad. Handl. 12(2): 69. 1933. Type: BRAZIL. Paraná, São Paulo: Balsa Nova, Curitiba, Serra da Bocaina, "Curityba 20/10 08 (n. 6906), Serrinha 14/10 09 (n. 8539). Hab. in campo. Ad eandem speciem pertinet Glaziou n. 7715 (in Serra da Bocaina civit. Sao Paulo lecta)", O', P. K. H. Dusén 6906 (lectotype S, S10-22254, designated by Barroso 1976: 97; duplicates G, G00222589 photo!, K, K000221944 photo!, NY, NY00162224 photo, US, US00129284 photo!).

\section{Lanugothamnus subg. Tarchonantoides} (Heering) Deble, comb. nov. Basyonim: Baccharis subg. Tarchonanthoides Heering Jahrb. Hamburg. Wiss. Anst. 21: 26. 1904. as "Tarchonantoides". Baccharis sect. Tarchonanthoides (Heering) Cuatrececasas, Revista Acad. Colomb. Ci. Exact. 13(49): 89. 1967. Type: Lanugothamnus tarchonanthoides (DC.) Deble [= Baccharis tarchonanthoides DC.].

Lanugothamus subg. Tarchonanthoides is characterized by ferrugineous indumentum, petiolate leaves, angulated, (3) 4-5-ribbed cypselae and pappus of pistillate flowers persistent, fused in a basal ring, not elongated at cypsela maturity. The subgenus comprises only two species, both endemic in southern Brazil (additional comments see Giuliano \& Freire 2011).

1. Lanugothamnus lychnophorus (Gardner) Deble, comb. nov. Basionym: Baccharis lychnophora Gardner, London, J. Bot 7: 85. 1848. Type: BRAZIL. Minas Gerais: Diamantina, "Moist rocky places on the high mountains of the Diamond District", VII-1840, ○', G. Gardner 4898 (holotype BM, not seen; isotypes B destroyed, F015009photo!, G, G00222623 photo!, NY, NY00162263 photo!, P, P00755476 photo!, US, US00129312 photo!).

$=$ ? Baccharis tarchonanthoides var. integrifolia Baker, Fl. Bras. (Martius) 6 (3): 50. 1882. Type: "in prov. S. Paulo: Sello n. 175!; in Minas Geraës ad Itambé: Martius!” (Type: not located, F20687 photo!)

2. Lanugothamnus tarchonanthoides (DC.) Deble, comb. nov. Basionym: Baccharis tarchonanthoides DC., Prodr 5: 414.1836. Type: BRAZIL. Minas Gerais: Mariana, "in Brasiliae prov. Minarum General cl. Vauthier "., 1833, O", A.C. Vauthier 275 (holotype G-DC, GDC00200472 photo!; isotypes G, G00169376 photo!, K, K000221895photo!, P, P00755763 photo!, P00755764 photo!).

= Baccharis ibitiensis Toledo, Arq. Bot. Estado São Paulo nova ser. f. maior, 3: 67. 1953. Type: BRAZIL. São Paulo: Amparo, Monte Alegre, "encosta do Pico da Serra Negra, 1200 m”, 30-VIII-1943, \&, M. Kuhlmann 1032 (holotype SP50262!; isotype RB114847!).

\section{NEW SPECIES}

During the review of herbarium specimens and collections of material two undescribed species of Lanugothamnus were discovery and are described below.

\section{Lanugothamnus pluricapitulatus Deble,} sp. nov. (Figure 3).

Lanugothamno subg. Toxicothamno sectioni Pluricephaliis pertinens, a Lanugothamno scabrifoliae affinis sed foliis discoloris, base attenuatis (non concoloris, base semi-amplexicaulis), capitulorum pistillatorum oblongum, 2.5-3 mm longum, 1-1.5 mm latum (non campanulatum ad late campanulatum 2.5-3 $\mathrm{mm}$ longum et latum), cypselis cum pilis geminis vestitis (non absentis), optime distincta. 
TABLE 1 - Morphological features in Lanugothamnus Deble.

\begin{tabular}{|c|c|c|c|c|c|c|}
\hline \multicolumn{7}{|c|}{ Lanugothamnus } \\
\hline Subgenus & \multicolumn{2}{|c|}{ Lanugothamnus } & \multicolumn{2}{|c|}{ Toxicothamnus } & \multirow[t]{2}{*}{ Curitybenses } & \multirow[t]{2}{*}{ Tarchonanthoides } \\
\hline Section & \multicolumn{2}{|c|}{\begin{tabular}{|l|l|} 
Lanugothamnus & Sericicarpa \\
\end{tabular}} & Toxicothamnus & Pluricephala & & \\
\hline Habit & \multicolumn{2}{|c|}{$\begin{array}{l}\text { subshrubs or shrubs, sometimes } \\
\text { with xylopodium and/or rhizome }\end{array}$} & $\begin{array}{l}\text { weakly wood } \\
\text { subshrubs, } \\
\text { with } \\
\text { xylopodium } \\
\text { and/or } \\
\text { rhizome }\end{array}$ & shrubs & shrubs & shrubs or small trees \\
\hline $\begin{array}{l}\text { Indumen- } \\
\text { tum colour }\end{array}$ & \multicolumn{2}{|c|}{ grayish-white or gray } & \multicolumn{2}{|c|}{$\begin{array}{l}\text { grayish-white, gray or } \\
\text { ochraceous }\end{array}$} & ferrugineous & $\begin{array}{l}\text { grayish-white and } \\
\text { ferrugineous }\end{array}$ \\
\hline $\begin{array}{l}\text { Leaf size } \\
\text { and } \\
\text { consistency }\end{array}$ & \multicolumn{2}{|c|}{$\begin{array}{l}\text { small to medium-sized, sessile, } \\
\text { thin or chartaceous }\end{array}$} & \multicolumn{2}{|c|}{$\begin{array}{l}\text { small, sessile, thin or } \\
\text { chartaceous }\end{array}$} & $\begin{array}{l}\text { medium-sized, } \\
\text { petiolate, } \\
\text { chartaceous or } \\
\text { coriaceous }\end{array}$ & $\begin{array}{l}\text { large, petiolate, } \\
\text { chartaceous or } \\
\text { coriaceous }\end{array}$ \\
\hline Venation & \multicolumn{2}{|c|}{$\begin{array}{l}\text { pinnately veined or seemingly } 1- \\
\text { veined }\end{array}$} & \multicolumn{2}{|c|}{$\begin{array}{l}\text { seemingly veinless or 1-veined } \\
\text { (obscurely reticulum-veined) }\end{array}$} & $\begin{array}{l}3 \text {-veined or } \\
\text { reticulum-veined }\end{array}$ & reticulum-veined \\
\hline $\begin{array}{l}\text { Staminate } \\
\text { and } \\
\text { pistillate } \\
\text { capitula }\end{array}$ & \multicolumn{2}{|c|}{$\begin{array}{l}\text { pistillate capitula campanulate, } \\
\text { staminate capitula campanulate or } \\
\text { hemispheric }\end{array}$} & \multicolumn{2}{|c|}{$\begin{array}{l}\text { pistillate capitula oblong or } \\
\text { campanulate, staminate capitula } \\
\text { hemispheric or cup-shaped }\end{array}$} & $\begin{array}{l}\text { hemispheric, similar } \\
\text { in shape and size }\end{array}$ & $\begin{array}{l}\text { campanulate, similar } \\
\text { in shape and size }\end{array}$ \\
\hline $\begin{array}{l}\text { Phyllaries } \\
\text { shape and } \\
\text { indumen- } \\
\text { tum }\end{array}$ & \multicolumn{2}{|c|}{$\begin{array}{l}\text { 4-6 seriate, acute or acuminate } \\
\text { (outermost phyllaries in staminate } \\
\text { capitula slightly obtuse), densely } \\
\text { clothed by lanose trichomes and } \\
\text { sericeous trichomes on dorsum } \\
\text { (except } L \text {. patens) }\end{array}$} & \multicolumn{2}{|c|}{$\begin{array}{l}\text { 2-4 seriate, slightly acute, } \\
\text { obtuse or rounded, with margin } \\
\text { hyaline and scariose, not or } \\
\text { densely clothed by lanose } \\
\text { trichomes on dorsum, and } \\
\text { glandular trichomes on margin }\end{array}$} & $\begin{array}{l}4-6 \text { seriate, slightly } \\
\text { acute or obtuse, } \\
\text { densely clothed by } \\
\text { lanose trichomes } \\
\text { and sericeous } \\
\text { trichomes on } \\
\text { dorsum }\end{array}$ & $\begin{array}{l}3-5 \text { seriate, acute or } \\
\text { obtuse, sparsely to } \\
\text { clothed by lanose } \\
\text { trichomes on } \\
\text { dorsum }\end{array}$ \\
\hline Receptacle & \multicolumn{2}{|c|}{$\begin{array}{l}\text { densely clothed by whitish } \\
\text { trichomes (flagelliform) }\end{array}$} & \multicolumn{2}{|c|}{ glandular trichomes sccatered } & $\begin{array}{l}\text { flagelliform } \\
\text { trichomes scattered }\end{array}$ & $\begin{array}{l}\text { flagelliform } \\
\text { trichomes scattered }\end{array}$ \\
\hline $\begin{array}{l}\text { Staminate/ } \\
\text { pistillate } \\
\text { flowers } \\
\text { ratio } \\
\end{array}$ & \multicolumn{2}{|l|}{$1: 1$} & $1: 1$ & $2: 1$ & $1: 1$ & $1: 1$ \\
\hline $\begin{array}{l}\text { Pistillate } \\
\text { flower } \\
\text { shape }\end{array}$ & \multicolumn{2}{|c|}{$\begin{array}{l}\text { tubular-filiform at the apex with } \\
\text { five acute teeth }\end{array}$} & \multicolumn{2}{|c|}{$\begin{array}{l}\text { broad tubular, at the apex with } \\
\text { five obtuse teeth }\end{array}$} & $\begin{array}{l}\text { tubular, at the apex } \\
\text { with five acute teeth }\end{array}$ & $\begin{array}{l}\text { tubular, at the apex } \\
\text { with five acute teeth }\end{array}$ \\
\hline $\begin{array}{l}\text { Staminate } \\
\text { flowers } \\
\text { shape }\end{array}$ & \multicolumn{2}{|c|}{ tube long, lobes lanceolate. } & \multicolumn{2}{|c|}{$\begin{array}{l}\text { tube short and thickened limb } \\
\text { differentiated, lobes short and } \\
\text { obtuse or nearly deltate }\end{array}$} & $\begin{array}{l}\text { tube medium-sized, } \\
\text { lobes lanceolate. }\end{array}$ & $\begin{array}{l}\text { tube long or } \\
\text { medium-sized, lobes } \\
\text { lanceolate. }\end{array}$ \\
\hline $\begin{array}{l}\text { Style of } \\
\text { pistillate } \\
\text { flowers }\end{array}$ & \multicolumn{2}{|c|}{$\begin{array}{l}\text { filiform, with oblong filiform } \\
\text { branches, and narrow stigmatic } \\
\text { region }\end{array}$} & \multicolumn{2}{|c|}{$\begin{array}{l}\text { broad cylindrical, with deltate } \\
\text { or broadly lanceolate branches, } \\
\text { and relative broad stigmatic } \\
\text { region }\end{array}$} & $\begin{array}{l}\text { cylindrical, with } \\
\text { lanceolate branches, } \\
\text { and narrow } \\
\text { stigmatic region }\end{array}$ & $\begin{array}{l}\text { cylindrical with } \\
\text { lanceolate branches } \\
\text { and narrow } \\
\text { stigmatic region }\end{array}$ \\
\hline $\begin{array}{l}\text { Style of } \\
\text { staminate } \\
\text { flowers }\end{array}$ & \multicolumn{2}{|c|}{$\begin{array}{l}\text { filiform with free lanceolate } \\
\text { branches, sweeping trichomes } \\
\text { abundant }\end{array}$} & \multicolumn{2}{|c|}{$\begin{array}{l}\text { short, with free or attached } \\
\text { broadly lanceolate or deltate } \\
\text { branches, sweeping trichomes } \\
\text { abundant }\end{array}$} & $\begin{array}{l}\text { filiform with free } \\
\text { lanceolate branches, } \\
\text { sweeping trichomes } \\
\text { abundant }\end{array}$ & $\begin{array}{l}\text { filiform with free } \\
\text { lanceolate branches, } \\
\text { sweeping trichomes } \\
\text { abundant }\end{array}$ \\
\hline Cypsela & $\begin{array}{l}\text { eglandular, } \\
\text { non } \\
\text { sericeous- } \\
\text { pubescent, } \\
\text { compressed, } \\
\text { 3-5-ribbed, } \\
\text { clothed by } \\
\text { short twin } \\
\text { trichomes on } \\
\text { ribs } \\
\text { concentrated }\end{array}$ & $\begin{array}{l}\text { eglandular, } \\
\text { sericeous- } \\
\text { pubescent, } \\
\text { compressed, 3- } \\
5 \text { - ribbed, } \\
\text { densely clothed } \\
\text { by very long } \\
\text { and acute twin } \\
\text { trichomes }\end{array}$ & \multicolumn{2}{|c|}{$\begin{array}{l}\text { non sericeous -pubescent, } \\
\text { angulated, } 4-7(-8) \text { ribbed, } \\
\text { clothed by biseriate glandular } \\
\text { trichomes with vesicular } \\
\text { terminal cells and/or biseriate } \\
\text { trichomes with asymmetric } \\
\text { terminal cells and asymmetric } \\
\text { twin trichomes with divergent } \\
\text { terminal cell. }\end{array}$} & $\begin{array}{l}\text { non sericeous- } \\
\text { pubescent, terete, 9- } \\
11 \text { ribbed, clothed } \\
\text { by twin trichomes } \\
\text { sccatered }\end{array}$ & $\begin{array}{l}\text { non sericeous- } \\
\text { pubescent angulated, } \\
\text { (3) } 4-5 \text { ribbed, } \\
\text { clothed by glandular } \\
\text { trichomes and sparse } \\
\text { short and } \\
\text { asymmetric twin } \\
\text { trichomes }\end{array}$ \\
\hline $\begin{array}{l}\text { Pappus of } \\
\text { staminate } \\
\text { flowers }\end{array}$ & \multicolumn{2}{|c|}{$\begin{array}{l}\text { 1-seriate (sometimes with } \\
\text { additional bristles), narrowed at } \\
\text { the apex. }\end{array}$} & \multicolumn{2}{|c|}{$\begin{array}{l}\text { few bristles, narrowed at the } \\
\text { apex }\end{array}$} & $\begin{array}{l}\text { 1-seriate, plumose at } \\
\text { the apex }\end{array}$ & $\begin{array}{l}\text { 1-seriate, narrowed } \\
\text { at the apex }\end{array}$ \\
\hline $\begin{array}{l}\text { Pappus of } \\
\text { pistillate } \\
\text { flowers }\end{array}$ & \multicolumn{2}{|c|}{$\begin{array}{l}\text { persistent (deciduous in } L \text {. } \\
\text { leucocephalus), 2-seriate, } \\
\text { elongated at cypsela maturity, } \\
\text { fused in a basal ring }\end{array}$} & $\begin{array}{l}\text { persistent, 2- } \\
\text { seriate, } \\
\text { elongated at } \\
\text { cypsela } \\
\text { maturity, } \\
\text { fused in a } \\
\text { basal ring }\end{array}$ & $\begin{array}{l}\text { persistent, 1- } \\
\text { seriate, not } \\
\text { (slightly) } \\
\text { elongated at } \\
\text { cypsela } \\
\text { maturity, } \\
\text { fused in a } \\
\text { basal ring }\end{array}$ & $\begin{array}{l}\text { deciduous, 2-seriate, } \\
\text { not elongated at } \\
\text { cypsela maturity }\end{array}$ & $\begin{array}{l}\text { persistent, 1-seriate, } \\
\text { not elongated at } \\
\text { cypsela maturity, } \\
\text { fused in a basal ring }\end{array}$ \\
\hline
\end{tabular}


Type: BRAZIL. Rio Grande do Sul: Pinheiro Machado, Serra das Asperezas, BR 293, km 113, on bogs and bog soils, staminate flowers, 5 March 2008, L. P. Deble \& A. S. de OliveiraDeble 8421 (holotype MBM!, isotypes CTES!, SI!).

Shrubs 1.5-2 m high; stems spreading, branching sympodial; young shoots gray pubescent, clothed by filiform trichomes with 800-2.500 $\mu \mathrm{m}$ long, at the base with 2-4 cells and a persistent terminal cell, flageliform trichomes, with 200-600 $\mu \mathrm{m}$ long, at the base 3-6 cells, and a deciduous terminal cell, and glandular trichomes scattered; older shoots ochre to darker, grooved or fissured. Leaves linear-oblong, linear-elliptic or linearoblanceolate, $6-35 \mathrm{~mm} \times 0.7-6 \mathrm{~mm}$, alternate, sessile, discolorous, margin entire, revolute, apex slightly acute, mucronate, base attenuate; leaf blades chartaceous, dark greenish brown, grayish brown or dark brown, seemingly glabrous or arachnoid pubescent, with lax or dense filiform trichomes adaxially and densely clothed by grayish-white trichomes abaxially. Capitulescence in terminal racemes composing dense terminal panicles of many capitula. Pistillate capitula oblong, $2.5-3 \mathrm{~mm} \times 1-1.5 \mathrm{~mm}$, involucre 2-2.5 $\mathrm{mm} \times 1-1.4 \mathrm{~mm}$, flowers 6-8. Phyllaries in 2-3 series, apex obtuse or rounded, often darker in the distal third, margins membranous, hyalines, dorsum with glandular trichomes. Outer phyllaries lanceolate or elliptic $0.7-1.2 \mathrm{~mm} \times 0.2-0.4 \mathrm{~mm}$, median phyllaries ovate, elliptic or obovate, $1.4-1.8 \mathrm{~mm} \times 0.5-0.8$ $\mathrm{mm}$ wide, inner phyllaries oblong or elliptic at the apex scariose, $1.8-2 \mathrm{~mm} \times 0.6-0.8 \mathrm{~mm}$. Receptacle conical, seemingly glabrous with sparse glandular trichomes. Corolla tubular, 1.2$1.6 \mathrm{~mm}$ long, with few glandular trichomes scattered, apically with 5 papillose teeth, up to $0.1 \mathrm{~mm}$ long. Style exceeding the corolla, 1.8$2.2 \mathrm{~mm}$ long; branches lanceolate, $0.4-0.5 \mathrm{~mm}$ long. Pappus of 24-30 bristles, 1-1.6 mm long, uniseriate, rigid, fused in a basal ring, persistent, not elongated at cypsela maturity, whitish.
Cypselae light brown, obovate-oblong, 0.7-0.8 $\mathrm{mm}$ long, laterally slightly compressed, with 5 longitudinal ribs and acute twin-trichomes, with 80-160 $\mu \mathrm{m}$ long, on ribs concentrate. Staminate capitula hemispheric, $1.8-2.5 \mathrm{~mm} \times 2.4-3.5 \mathrm{~mm}$, involucre 1.6-2 $\mathrm{mm} \times 2.4-2.6 \mathrm{~mm}$, flowers 814. Phyllaries in 2-3 series, apex acute or rounded, often darker in the distal third, margins membranous, hyalines, dorsum with glandular trichomes. Outer phyllaries lanceolate or oblong, 0.8-1.2 $\mathrm{mm} \times 0.2-0.4 \mathrm{~mm}$, median and inner phyllaries obovate, $1.4-1.8 \mathrm{~mm} \times 0.6-0.9 \mathrm{~mm}$. Receptacle conical, seemingly glabrous with sparse glandular trichomes. Corolla 1.4-1.8 mm long, apically with 5 deltate lobes, $0.4-0.5 \mathrm{~mm}$ $\times 0.4 \mathrm{~mm}$, tube with $0.9-1 \mathrm{~mm}$ long with trichomes scattered in the distal half. Anthers $0.5-0.6 \mathrm{~mm}$ long. Style not or slightly exceeding the corolla, $1.5-1.7 \mathrm{~mm}$ long; style branches with ca. $0.2 \mathrm{~mm}$ long, attached or free. Pappus of 1126 bristles, $1-1.5 \mathrm{~mm}$ long, uniseriate, undulate, deciduous, ending in two acute papillae, whitish. Cypselae abortive, obconical, ca. $0.1 \mathrm{~mm}$ long.

Distribution and Habitat: Lanugothamnus pluricapitulatus occurs in Southern Brazil, endemic on bogs and bog soils from Serra do Sudeste in southeast Rio Grande do Sul State, growing at elevations between $300-400 \mathrm{~m}$.

Etymology: The new species is named by the number of capitula.

Comments: Lanugothamnus pluricapitulatus belongs to Lanugothamnus subg. Toxicothamnus sect. Pluricephala Deble, and it is closely related to L. scabrifolius (G. Heiden) Deble, both species display similar habit, capitulescence, shape and size of staminate capitula, and pistillate flowers with uniseriate pappus, not (or slightly) elongated at the cypsela maturity. In addition, both species grow on bogs and bog soils, in contrast to other species of $L$. subg. Toxicothamnus found on grasslands and dry grasslands. Lanugothamnus pluricapitulatus differs from L. scabrifolius by its discolorous, at the base attenuate leaves (vs. concolorous, at the base semi-amplexicaul leaves), densely 


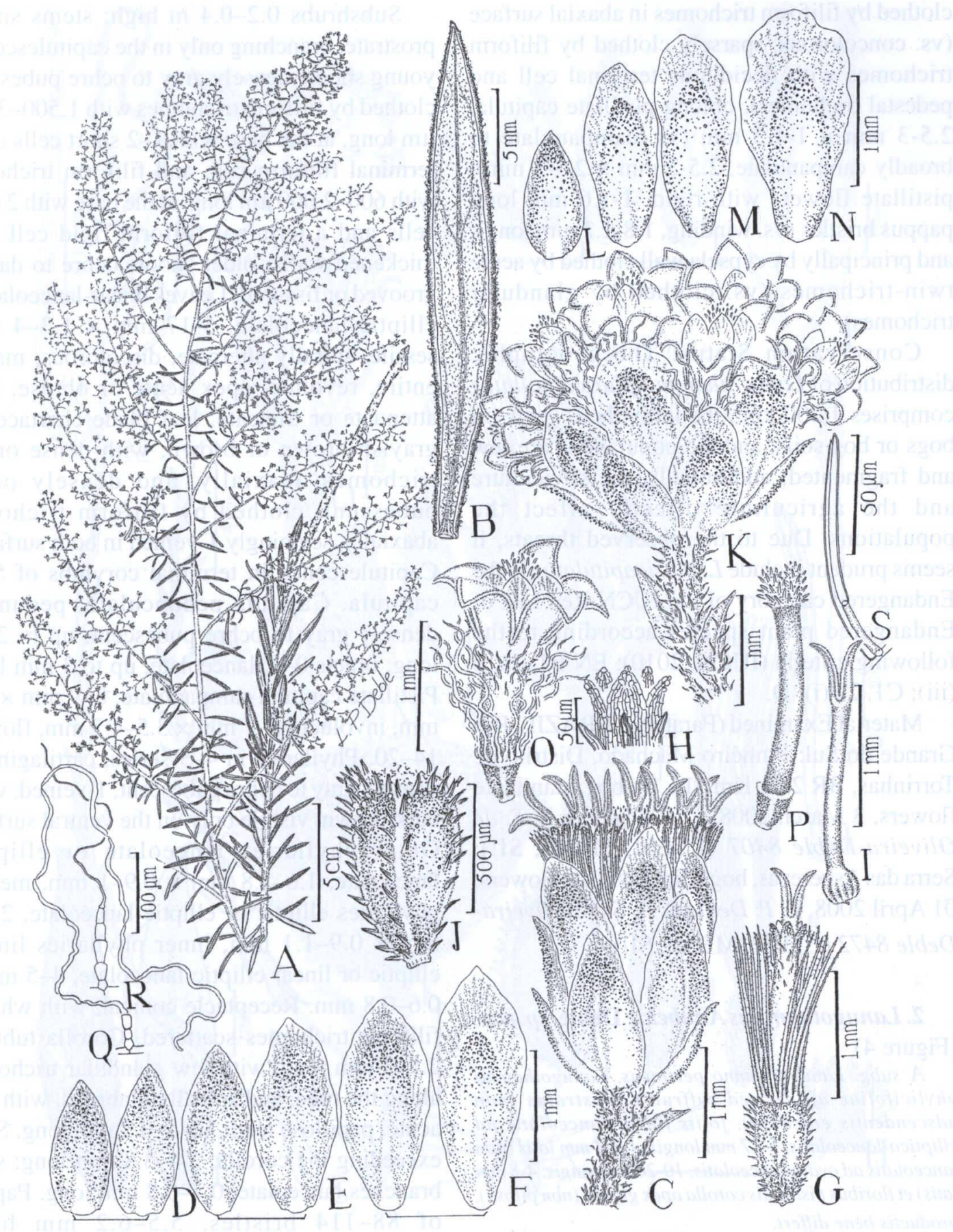

FIGURE 3 - Lanugothamnus pluricapitulatus. A. Staminate plant. B. Leaf, abaxial surface. C. Pistillate capitulum. D-F. Pistillate capitulum phyllaries. D. Outer phyllaries. E. Middle phyllaries. F. Inner phyllaries. G. Pistillate flower. H. Corolla apex of pistillate flower. I. Pistillate flower style. J. Cypsela. K. Staminate capitulum. L-N. Staminate capitulum phyllaries. L. Outer phyllary. M. Middle phyllaries. N. Inner phyllary. O. Staminate flower. P. Style of staminate flower. Q. Filiform trichome from leaf. R. Flageliform trichome from leaf. S. Twin trichome from cypsela (A-B, K-R from Deble \& Oliveira-Deble 8421 MBM, C-J, S from Deble \& Oliveira-Deble 8472 MBM). 
clothed by filiform trichomes in abaxial surface (vs. concolorous, sparsely clothed by filiform trichomes with deciduous terminal cell and pedestal trichomes), oblong pistillate capitula, 2.5-3 $\mathrm{mm} \times 1-1.5 \mathrm{~mm}$ (vs. campanulate to broadly campanulate, $2.5-3 \mathrm{~mm} \times 2.5-3 \mathrm{~mm}$ ), pistillate flowers with rigid, $1-1.6 \mathrm{~mm}$ long pappus bristles (vs. winding, 1.8-2.2 $\mathrm{mm}$ long), and principally by cypsela wall clothed by acute twin-trichomes (vs. clothed by glandular trichomes).

Conservation Status: The geographic distribution of Lanugothamnus pluricapitulatus comprises $1,200 \mathrm{~km}^{2}$, the individuals grow on bogs or bog soils, and the populations are few and fragmented; additionally, the silviculture and the agriculture directly affect the populations. Due to the observed threats, it seems prudent include L. pluricapitulatus in the Endangered category of the IUCN Red List of Endangered plant species according to the following criteria (IUCN, 2010): EN B1, 2a, b (iii); C1, 2a (i); D.

Material Examined (Paratypi): BRAZIL. Rio Grande do Sul: Pinheiro Machado, Distrito de Torrinhas, BR 293, Km 116, on bog, staminate flowers, 3 March 2008, L. P. Deble \& A. S. de Oliveira-Deble 8407 (CTES!, MBM!, SI!); Serra das Asperezas, bog soils, pistillate flowers, 01 April 2008, L. P. Deble \& A. S. de OliveiraDeble 8472 (CTES!, MBM!, SI!).

2. Lanugothamnus Anabelae Deble, sp. nov. (Figure 4)

A subg. Lanugothamno pertinens, Lanugothamno phylicifoliae affinis sed suffrutex prostratus (non adscendentis erectisve), foliis linear-lanceolatis ad elliptico-lanceolatis, 5-17 mm longis, 1.3-4 mm latis (non lanceolatis ad ovato-lanceolatis, $10-20 \mathrm{~mm}$ longis, 4-8 mm latis) et floribus pistillatis corolla apex glabra (non pilosa), productis bene differt.

Type: BRAZIL. Rio Grande do Sul: São José dos Ausentes, Canion Monte Negro, on bogs and adjacent bog soils, $1000 \mathrm{~m}$, pistillate flowers, 7 November 2005, L. P. Deble \& A. S. OliveiraDeble 4128 (holotype MBM!, isotype SI!).
Subshrubs $0.2-0.4 \mathrm{~m}$ high; stems single, prostrate, branching only in the capitulescence; young shoots densely gray to ochre pubescent, clothed by filiform trichomes with 1.500-3.000 $\mu \mathrm{m}$ long, at the base with 1-2 short cells and a terminal filiform cell, and filiform trichomes with 600-2.000 $\mu \mathrm{m}$ long, at the base with 2 short cells and a terminal filiform rigid cell with thickened walls; older shoots ochre to darker, grooved or fissured. Leaves linear-lanceolate or elliptic-lanceolate, $5-17 \mathrm{~mm} \times 1.3-4 \mathrm{~mm}$, sessile, spirally alternate, discolorous, margin entire, revolute, apex acute or obtuse, base attenuate or truncate; leaf blade chartaceous, grayish-brown or brown, with dense or lax trichomes adaxially, and densely ochre pubescent, clothed by filiform trichomes abaxially, seemingly 1-veined in both surfaces. Capitulescence in terminal corymbs of 5-26 capitula. Capitula pedunculate; peduncles densely gray to ochre pubescent, up to $2 \mathrm{~cm}$ long; bracts $0-1$, lanceolate, up to $3 \mathrm{~mm}$ long. Pistillate capitula campanulate, $8-9 \mathrm{~mm} \times 4-6$ $\mathrm{mm}$, involucre 5-7 $\mathrm{mm} \times 3.5-4.5 \mathrm{~mm}$, flowers 14-20. Phyllaries in 4-5 series, cartilaginous, densely gray to ochre pubescent, 1 -veined, veins dark brown, visible only on the ventral surface. Outer phyllaries lanceolate or ellipticlanceolate, $1.6-2.8 \mathrm{~mm} \times 0.9-1 \mathrm{~mm}$, median phyllaries elliptic or elliptic-lanceolate, 2.8-4 $\mathrm{mm} \times 0.9-1.1 \mathrm{~mm}$, inner phyllaries linearelliptic or linear elliptic-lanceolate, 4-5 $\mathrm{mm} \times$ $0.6-0.8 \mathrm{~mm}$. Receptacle conical, with whitish filiform trichomes scattered. Corolla tubular, 2.5-3 mm long, with few glandular trichomes along the tube, and apically glabrous, with five acute, papillose teeth, up to $0.2 \mathrm{~mm}$ long. Style exceeding the corolla, 3.4-3.8 mm long; style branches lanceolate, $0.7-0.8 \mathrm{~mm}$ long. Pappus of 88-114 bristles, 5.5-6.2 mm long, multiseriate, fused in a basal ring, persistent, slightly elongated at cypsela maturity, gray or grayish-white. Cypselae oblong, 1.2-1.6 mm long, light brown, compressed, 4 (5) ribbed, with twin-trichomes with $40-80 \mu \mathrm{m}$ long on ribs concentrate. Staminate capitula nearly 


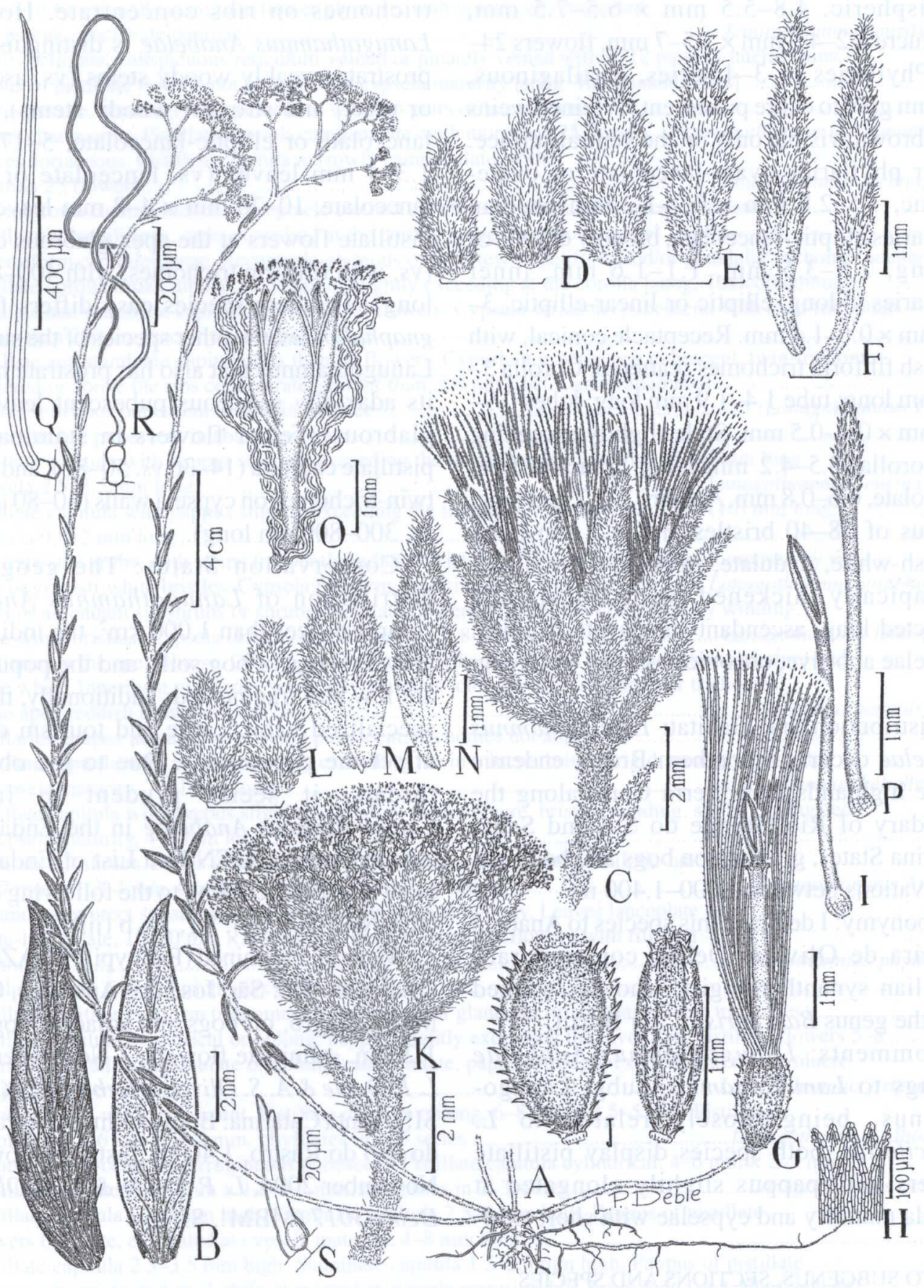

FIGURE 4 - Lanugothamnus Anabelae. A. Pistillate plant. B. Leaf, adaxial and abaxial surfaces. C. Pistillate capitulum. D-F. Pistillate capitulum phyllaries. D. Outer phyllaries. E. Middle phyllaries. F. Inner phyllaries. G. Pistillate flower. H. Corolla apex of pistillate flower. I. Pistillate flower style. J. Cypsela, frontal and lateral view. K. Staminate capitulum. L-N. Staminate capitulum phyllaries. L. Outer phyllaries. M. Middle phyllary. N. Inner phyllary. O. Staminate flower. P. Style of staminate flower. Q. Filiform trichome from leaf. R. Filiform trichome with rigid terminal cell from leaf. S. Twin trichome from cypsela (A-J, Q-S from Deble \& Oliveira-Deble $4128 \mathrm{MBM}, \mathrm{K}-\mathrm{P}$ from Deble \& OliveiraDeble 4129 MBM). 
hemispheric, $4.8-5.5 \mathrm{~mm} \times 6.5-7.5 \mathrm{~mm}$, involucre $3.2-4.5 \mathrm{~mm} \times 5.5-7 \mathrm{~mm}$, flowers 24 30. Phyllaries in 3-4 series, cartilaginous, dorsum gray to ochre pubescent, 1-veined, veins dark brown, visible only on the ventral surface. Outer phyllaries ovate-lanceolate or ovateelliptic, $1.5-2.8 \mathrm{~mm} \times 0.9-1.2 \mathrm{~mm}$, median phyllaries elliptic-lanceolate, broadly elliptic or oblong, 2.5-3.5 mm, 1.1-1.6 mm, inner phyllaries oblong, elliptic or linear-elliptic, 3$3.8 \mathrm{~mm} \times 0.6-1.4 \mathrm{~mm}$. Receptacle conical, with whitish filiform trichomes scattered. Corolla $3-$ $3.8 \mathrm{~mm}$ long; tube 1.4-1.9 mm long; lobes 0.9$1.1 \mathrm{~mm} \times 0.4-0.5 \mathrm{~mm}$. Style slightly exceeding the corolla, 3.5-4.2 mm long; branches free, lanceolate, $0.6-0.8 \mathrm{~mm}$. Anthers $1-1.2 \mathrm{~mm}$ long. Pappus of $28-40$ bristles, $3.5-4.5 \mathrm{~mm}$ long, grayish-white, undulate, fused in a basal ring and apically thickened, with apical cells projected long, ascendant subclavate papillae. Cypselae abortive, obconical, ca. $0.1 \mathrm{~mm}$ long.

Distribution and Habitat: Lanugothamnus Anabelae occurs in Southern Brazil, endemic to the highlands from Serra Geral along the boundary of Rio Grande do Sul and Santa Catarina States, growing on bogs and bog soils at elevations between 1,000-1,400 m.

Eponymy: I dedicate this species to Anabela Silveira de Oliveira-Deble, contemporary Brazilian synantherologist, who has worked with the genus Baccharis s.l. for Brazil.

Comments: Lanugothamnus Anabelae belongs to Lanugothamnus subg. Lanugothamnus, being closely related to $L$. phylicifolius, both species display pistillate flowers with pappus slightly elongated at cypsela maturity and cypselae with short twin- trichomes on ribs concentrate. However, Lanugothamnus Anabelae is distinguished by prostrate, weakly woody stems (vs. ascendant or erect, and stronger woody stems), linearlanceolate or elliptic-lanceolate, 5-17 $\mathrm{mm} \times$ 1.3-4 mm leaves (vs. lanceolate or ovatelanceolate, 10-20 $\mathrm{mm} \times 4-8 \mathrm{~mm}$ leaves), and pistillate flowers at the apex glabrous corollas (vs. with filiform trichomes, with 400-800 um long). The new species easy differs from $L$. gnaphalioides, the other species of the subgenus Lanugothamnus that also has prostrate habit by its adaxially sericeous pubescent leaves (vs. glabrous), fewer flowers in staminate and pistillate capitula (14-30 vs. 50-80), and shorter twin-trichomes on cypsela walls (40-80 $\mu \mathrm{m}$ long vs. 300-800 $\mu \mathrm{m}$ long).

Conservation Status: The geographic distribution of Lanugothamnus Anabelae comprises lees than $1,000 \mathrm{~km}^{2}$, the individuals grow on bogs or bog soils, and the populations are few and fragmented; additionally, the high specialized habit, cattle and tourism directly affect the populations. Due to the observed threats, it seems prudent to include Lanugothamnus Anabelae in the Endangered category of the IUCN Red List of Endangered plant species according to the following criteria (IUCN, 2010): EN, B1, 2a, b (iii); D.

Material Examined (Paratypi): BRAZIL. Rio Grande do Sul: São José dos Ausentes, Canion Monte Negro, on bogs and adjacent bog soils, $1,200 \mathrm{~m}$, staminate flowers, 7 November 2005 , L. P. Deble \& A. S. Oliveira-Deble 4129 (MBM! SI!). Santa Catarina: Bom Jardim da Serra, Serra do Rio do Rastro, 1,400m, pistillate flowers, 4 November 2004, L. P. Deble \& A. S. OliveiraDeble 3017 (MBM!, SI!).

\section{KEY TO SUBGENUS, SECTIONS AND SPECIES}

1. Cypsela terete, 9-11-ribbed. Pappus of pistillate flowers not fused in a basal ring, deciduous [subg. Curitybenses].

- Cypsela angulated or compressed 3-8-ribbed. Pappus of pistillate flowers fused in a basal ring, persistent (deciduous in L. leucocephalus)

2. Leaf base attenuate in a pseudopetiole. Cypsela obconical, 2.4-3.2 $\mathrm{mm}$ long, sparsely clothed by twin-trichomes. Pappus of functionally staminate flower non-plumose, with apical cells projected long, erect, acute papillae Lanugothamnus chionolaenoides

- Leaf base distinctly petiolate. Cypsela cylindrical, $1.3-1.8 \mathrm{~mm}$ long, densely clothed by twin-trichomes. 
Pappus of functionally staminate flower plumose, with apical cells projected long patent, subclavate papillae

3. Leaves petiolate, conspicuous reticulum-veined or pinately veined with 6-12 pairs of lateral veins.

Pappus of pistillate flowers not elongated at cypsela maturity [subg. Tarchonanthoides] ...................................... 4

- Leaves sessile, seemingly 1-3-veined, or with 1-5 pairs of lateral veins

4. Leaves chartaceous. Pistillate capitula campanulate, with more than 25 flowers ... Lanugothamnus tarchonanthoides

- Leaves coriaceous. Pistillate capitula narrowly campanulate, with less than 25 flowers Lanugothamnus lychnophorus

5. Corymbiform capitulescence. Receptacle clothed by whitish filiform trichomes. Pistillate corolla tubular-filiform, style exceeding at the corolla [subg. Lanugothamnus]

- Racemiform capitulescence. Receptacle glabrous or with few flageliform and/or glandular trichomes scattered. Pistillate corolla broad tubular, style not or slightly exceeding at the corolla [subg. Toxicothamnus] ................. 13

6. Pistillate and staminate capitula more than 50 flowers. Cypsela sericeous pubescent, with twin-trichomes longer than $200 \mu \mathrm{m}$ [sect. Sericicarpa] ....................................................................................................

- Pistillate and staminate capitula less than 50 flowers. Cypsela non sericeous pubescent, twin-trichomes scattered or above the ribs concentrate, shorter than $200 \mu \mathrm{m}$ [sect. Lanugothamnus] .......................................... 10

7. Leaves sericeous pubescent in abaxial surface Lanugothamnus Gibertii

- Leaves lanose pubescent in abaxial surface

8. Pistillate capitula with pappus strongly exceeding the involucre, bristles with $13-16 \mathrm{~mm}$ long. Cypsela 2.5-3.5 mm long ................................................................................ Lanugothamnus leucocephalus

- Pistillate capitula with pappus slightly exceeding the involucre, bristles with 3.5-8 (10) mm long. Cypsela 0.8-2 mm long.

9. Prostrate subshrubs, with stems frequently radicant. Pistillate flowers with pappus composed by rigid, gray or grayish-white bristles. Cypsela fusiform, stramineous, $1.5-2 \mathrm{~mm}$ long ....... Lanugothamnus gnaphalioides

- Erect or ascendant subshrubs or shrubs. Pistillate flowers with pappus composed by winding, shine white bristles. Cypsela oblong, reddish-brown, 0.8-1 mm long ....................... Lanugothamnus leucopappus

10. Phyllaries at the apex obtuse. Outermost phyllaries clothed by lanose trichomes strongly adpressed, shine white. Innermost phyllaries seemingly glabrous (clothed only by glandular trichomes), at the apex reddish brown or purplish Lanugothamnus patens

- Phyllaries at apex acute, gray or ochre pubescent, trichomes not adpressed

11. Pistillate capitula with pappus strongly exceeding the involucre; bristles rigid, strongly elongated at cypsela maturity, $7-11 \mathrm{~mm}$ long ......................................................................... Lanugothamnus helichrysoides

- Pistillate capitula with pappus slightly exceeding the involucre, bristles winding, slightly elongated at cypsela maturity, 4-7 $\mathrm{mm}$ long

12. Prostrate subshrubs. Stems weakly woody. Leaves linear-lanceolate to elliptic-lanceolate, 5-17 mm $\times 1.3-4 \mathrm{~mm}$. Corolla of pistillate flowers glabrous

Lanugothamnus Anabelae

- Ascendant or erect subshrubs or shrubs. Stems stronger woody. Leaves lanceolate to ovate-lanceolate, $10-20 \mathrm{~mm} \times 4-8 \mathrm{~mm}$. Corolla of pistillate flowers with filiform trichomes

Lanugothamnus phylicifolius

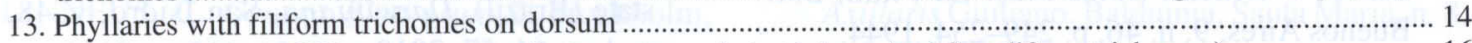

_ Phyllaries without filiform trichomes (indumentum of glandular or/and flageliform trichomes) ......................... 16

14. Pistillate capitula cylindrical or oblong, pappus slightly exceeding the involucre. Pistillate flowers 5-8 ............. 15

- Pistillate capitula campanulate or oblong-campanulate, pappus strongly exceeding at the involucre.

Pistillate flowers $10-15$

15. Plants grayish-white pubescent. Pistillate capitula oblong, $6-8 \mathrm{~mm} \times 3.5-5 \mathrm{~mm}$. Pistillate involucre $4.5-6 \mathrm{~mm} \times 3-4 \mathrm{~mm}$, phyllaries in $4-5$ series .....

Lanugothamnus albolanosus

- Plants grayish-ochre or ferrugineous pubescent. Pistillate capitula cylindrical, 4-6 $\mathrm{mm} \times 2-3 \mathrm{~mm}$. Pistillate involucre 3-4 $\mathrm{mm} \times 1.8-2.2 \mathrm{~mm}$, phyllaries in 2-3 series ............................ Lanugothamnus ochraceus

16. Pistillate capitula 6-10 $\mathrm{mm}$ high. Staminate capitula $2.5-8 \mathrm{~mm}$ high. Pappus of pistillate flowers biseriate, elongated at cypsela maturity, 4-8 $\mathrm{mm}$ long

- Pistillate capitula 2.5-3.5 mm high. Staminate capitula 1.5-2.5 mm high. Pappus of pistillate flowers uniseriate, not or slightly elongated at cypsela maturity, 1-2.2 $\mathrm{mm}$ long [sect. Pluricephala]

17. Leaves oblong 20-50 $\mathrm{mm} \times 3-8 \mathrm{~mm}$, conspicuous 3-veined. Internodes up to $40 \mathrm{~mm}$. Pistillate capitula broadly campanulate, $4-6 \mathrm{~mm}$ wide ................................................ Lanugothamnus erigeroides

- Leaves linear, linear-lanceolate or linear-oblong, 10-40 $\mathrm{mm} \times 0.8-3 \mathrm{~mm}$, seemingly 1-veined. Internodes up to $20 \mathrm{~mm}$. Pistillate capitula cylindrical or narrowly campanulate, 2-4 mm wide 18

18. Stem solitary, branching in the distal third. Leaves adpressed at the stem Lanugothamnus suberectifolius

- Stem branched. Leaves not adpressed at the stems 19 
19. Leaves concolorous, both surfaces greenish brown, olive brown or dark brown, with lax filiform trichomes with deciduous terminal cell Lanugothamnus montevidensis subsp. montevidensis

- Leaves slightly discolorous, grayish-green or greenish brown adaxially, and grayish-green abaxially, with laxe to dense filiform trichomes with persistent terminal cell Lanugothamnus montevidensis subsp. bicolor

20. Leaves semiamplexicaul, concolorous. Pistillate capitula campanulate or broadly campanulate, 2.5-3 mm wide. Pistillate flowers pappus winding, 1.8-2.2 mm long. Cypselae clothed by glandular trichomes Lanugothamnus scabrifolius

- Leaves attenuate, discolorous. Pistillate capitula oblong, 1-1.5 mm wide. Pistillate flowers pappus rigid, 1-1.6 mm long. Cypselae clothed by twin-trichomes Lanugothamnus pluricapitulatus

\section{ACKNOWLEDGMENTS}

I would like to thank Bolivar Nunes for his help on the English version of this material and my gratitude also goes to José Newton Cardoso Marchiori by helpful comments of manuscript.

\section{REFERENCES}

ARECHAVAlETA, J. Flora Uruguaya. Anales Museo Nacional Montevideo, Montevideo, v. 6, n. 3, p. 1-502. 1908.

BARROSO, G. M. Baccharidiopsis, um gênero novo da subtribo Baccharidinae Hoffman (tribo Astereae). Sellowia, Itajaí, v. 6, p. 95-101. 1975.

BARROSO, G. M. Compositae - Subtribo Baccharidinae Hoffmann. Estudo das espécies ocorrentes no Brasil. Rodriguésia, Rio de Janeiro, v. 28, n. 40, p. 1-273. 1976.

CABRERA, Á. L. Compuestas argentinas nuevas o interesantes. Notas Mus. La Plata. Bot. Buenos Aires, v. 2, n. 16, p. 171-204. 1937.

CABRERA, Á. L. Compuestas Sudamericanas nuevas o críticas. Notas Mus. La Plata, Bot. Buenos Aires, 9, n. 46, p. 249-254. 1944.

CABRERA Á. L. La identidad del género Psila Philippi. Bol. Soc. Argent. Bot., Córdoba, v. 5, p. 209-211. 1955.

CABRERA, Á. L. Compuestas. In CABRERA, Á. L. (ed.): Flora de la Provincia de Buenos Aires. Buenos Aires, Instituto Nacional de Tecnología Agropecuaria, v. 6, 1963.

CABRERA, Á. L. Compositae. In: CORREA, M. N. (ed.): Flora patagonica. Buenos Aires, Instituto Nacional de Tecnología Agropecuaria, v. 7, 1971.

CABRERA, Á. L. Compositae, compuestas. In: BURKART, A. (ed.): Flora ilustrada de Entre Ríos (Argentina). Buenos Aires: Instituto Nacional de Tecnología Agropecuaria, v. 6, p. 106538.
CABRERA, Á. L. Compositae. In: CABRERA, Á. L. (ed.): Flora de la Provincia de Jujuy. Buenos Aires, Instituto Nacional de Tecnología Agropecuaria, v. 10, 1978.

CUATRECASAS, J. Revisión de las especies colombianas del género Baccharis. Rev. Acad. Colomb. Ci. Exact., Bogotá, v. 13. N. 49, p. 5-102. 1967.

CUATRECASAS, J. Prima flora Colombiana. 3. Compositae-Astereae. Webbia, Florence, v. 24, n. 1, p. 1-335. 1969.

DEBLE, L. P.; OLIVEIRA, A. S. de; MARCHIORI, J. N. C. Heterothalamulopsis, gênero novo da subtribo Baccharinae Lessing (AstereaeAsteraceae). Ciência Florestal, Santa Maria, v. 14, n. 1, p. 1-7. 2004.

DEBLE, L. P.; OLIVEIRA, A. S. de; MARCHIORI, J. N. C. O Gênero Heterothalamus Less. (Asteraceae, Astereae) e táxones afins. Balduinia, Santa Maria, n. 1, p. 1-21. 2005.

FALKENBERG, D. de B.; DEBLE, L. P. Baccharis chionolaenoides (Asteraceae), a new species of subgenus Tarchonantoides from Santa Catarina state (Brazil). Darwiniana, San Isidro, v. 48, n. 1, p. 64-67. 2010.

GIULIANO, D. Asteraceae, parte 15. Tribu III. Astereae, parte A. Subtribu c. Baccharidinae. Flora Fanerogámica Argentina, Córdoba, n. 66, p. 1-74. 2000.

GIULIANO, D. Clasificación infragenérica de las especies argentinas de Baccharis (Asteraceae, Astereae). Darwiniana, San Isidro, v. 39, n. 12, p. 131-154. 2001

GIULIANO, D. New infragenera in Baccharis (Asteraceae, Astereae). Novon, San Francisco, v. 15 , n. 4 , p. 535-541. 2005.

GIULIANO, D. A; FREIRE, S. E. Nuevas secciones en Baccharis (Asteraceae: Astereae) de America del Sur. Annals of the Missouri Botanical Garden, Missouri, v. 98, n. 3, p. 331-347. 2011 
HEERING, W. C. Die Baccharis-Arten des Hamburger Herbars. Jahrb. Hamburg. Wiss. Anst. Beih., Hamburg, v. 21, p. 1-46. 1904.

HEERING, W. C. Systematische und pflanzengeographische Studien über die BaccharisArten des außertropischen Südamerikas. Jahrb. Hamburg. Wiss. Anst., Beih., Hamburg, v. 3, p. 63-173. 1915.

HELLWIG, F. H. Die Gattung Baccharis L. (Compositae - Astereae) in Chile. Mitt. Bot. Staatssamml. München, München, v. 29, p. 1456. 1990.

HELLWIG, F. H.. Untersuchungen zur Behaarung ausgewählter Astereae (Compositae). Flora, Jena, n. 186, 425-444.

HELLWIG, F. H. The genera Pingraea Cassini and Neomolina Hellwig (Compositae-Astereae). Candollea, Geneve, v. 48, p. 203-219. 1993

HELLWIG, F. H. Taxonomy and evolution of Baccharidinae (Compositae). In: Hind, D. J. N.; Beentje, H. J. (ed.). Compositae: Systematics. Proceedings of the International Compositae Conference Kew, Kew 1, p. 575-590. 1996.

IUCN (2010) Guidelines for Using the IUCN Red List Categories and Criteria. Version 2010. 8.1. Prepared by the Standards and Petitions SubCommittee in March 2010. from:http:// intranet.iucn.org/webfiles/doc/SSC/RedList/ RedListGuidelines. (accessed: 22 July 2011).

JACKSON, J. D. A revision of the genus Archibaccharis Heering (Compositae-Astereae). Phytologia, New York, v. 32, p. 81-194.

LINNEUS, C. Genera Plantarum 2. Stockholm, 1763, p. 561-1200p.

MALAGARRIGA HERAS, R. P. Notes critiques a propos des Baccharidinae de l'herbier du Laboratoire de Phanérogamie du Museum d'Histoire Naturelle de Paris. Bull. Mus. Nat. Hist. Nat., Paris, v. 2, n. 30, p. 275-298. 1958

MALAGARRIGA HERAS, R. Nomenclator Baccharidinarum Omnium. Mem. Soc. Cien. Nat. La Salle, v. 37, p. 129-224. 1977.

MÜLLER, J. (2006) Systematics of Baccharis (Compositae-Astereae) in Bolivia, including an overview of the genus. Systematic Botany Monographs, Michigan, v.76, 339 pp.

NESOM, G. L. Baccharis monoica (Compositae: Astereae), a monoecius species of the $B$. salicifolia complex from Mexico and Central
America. Phytologia, New York, v. 65, n. 2, 160164. 1988a.

NESOM, G. L. Baccharis sect. Baccharidastrum (Asteraceae: Astereae), including two monoecious and one dioecious species. Phytologia, New York, v. 65, n. 2, 169-173. 1988b.

NESOM, G. L. Two new species of Mexican Baccharis (Asteraceae: Astereae). Phytologia, New York, v. 69, n. 1, 32-39. 1990a.

NESOM, G. L. Infrageneric taxonomy of North and Central American Baccharis (Asteraceae: Astereae). Phytologia, New York, v. 69, n. 1, 40-46. 1990b.

NESOM, G. L. Subtribal classification of the Astereae (Asteraceae). Phytologia, New York, v. 76, n. 3, p. 193-274. 1994.

NESOM, G. L. Two newly recognized species of Baccharis from Mexico. Phytologia, New York, v. 84, n. 1, 50-52. 1998.

NESOM, G. L. Generic conspectus of the tribe Astereae (Asteraceae) in North America and Central America, the Antilles, and Hawaii. Sida, Texas, v. 20, n. 1, p. 1-100. 2000.

OLIVEIRA, A. S. de; MARCHIORI, J. N. C. Baccharis L. (Asteraceae-Astereae) no sul do Brasil 1. Seção Cylindricae Heering, Série Cylindricae (Heering) Giuliano. Balduinia, Santa Maria, n. 7, p. 1-36. 2006a.

OLIVEIRA, A. S. de; MARCHIORI, J. N. C. Baccharis L. (Asteraceae-Astereae) no sul do Brasil. 2. Seção Cylindricae Heering, Série Axillaris Giuliano. Balduinia, Santa Maria, n. 8, p. 1-21. 2006b.

OLIVEIRA, A. S. de; DEBLE, L. P.; SCHNEIDER, A. A.; MARCHIORI, J. N. Checklist do gênero Baccharis L. para o Brasil (Asteraceae-Astereae). Balduinia, Santa Maria, n. 9, p. 17-27.

OLIVEIRA-DEBLE, A. S. Classificação infragenérica e atualização nomenclatural das espécies brasileiras de Baccharis L. (AsteraceaeAstereae). Tese de Pós-graduação em Engenharia Florestal. Universidade Federal de Santa Maria, Brasil, 234pp. 2008.

SCHNEIDER, A. A. Estudo Taxonômico de Baccharis L. sect. Caulopterae (AsteraceaeAstereae) no Brasil. Tese de Pós-Graduação em Botânica. Universidade Federal do Rio Grande do Sul, Brasil, 201pp. 2009. 